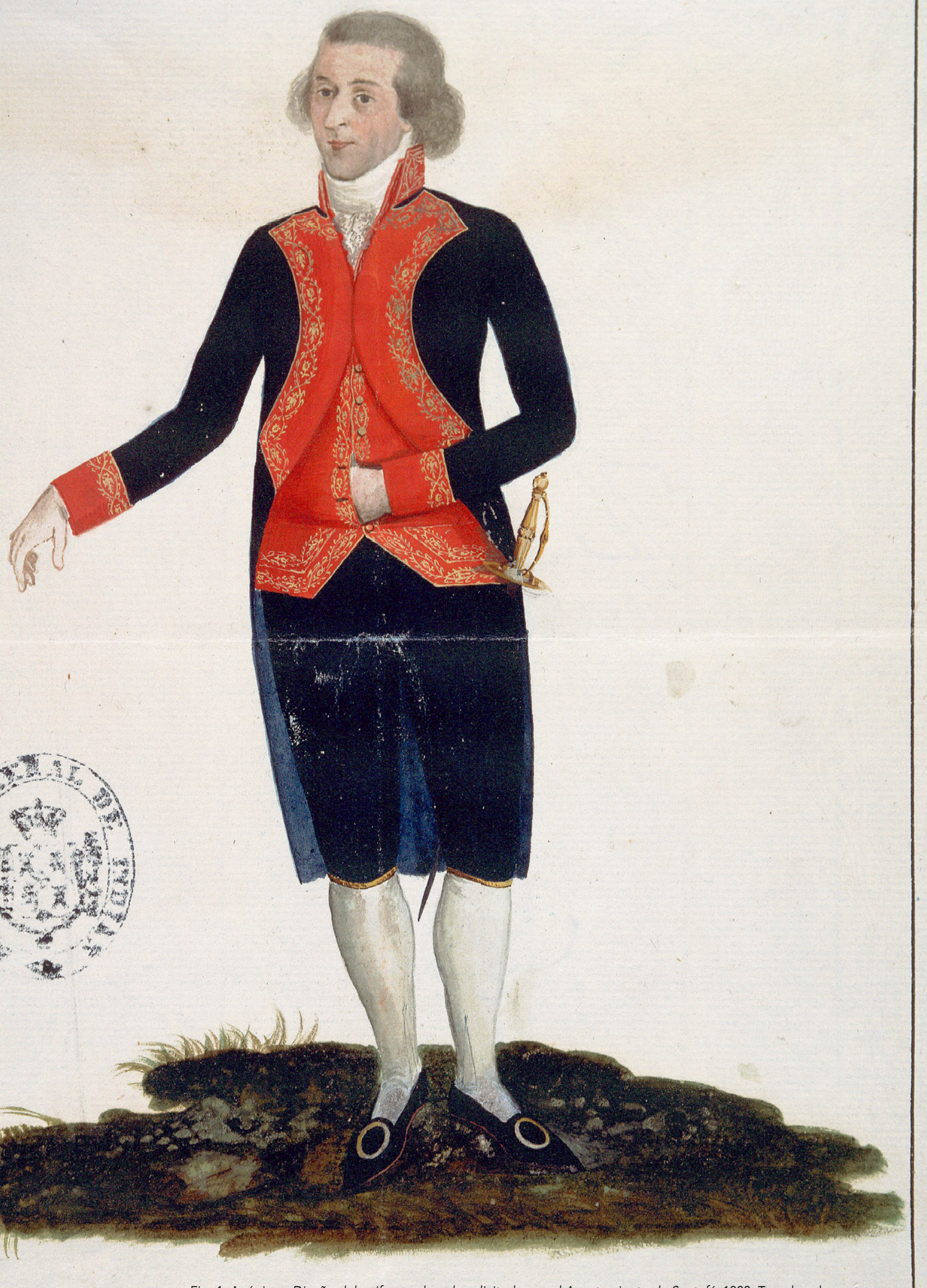

Fig. 1. Anónimo, Diseño del uniforme de gala solicitado por el Ayuntamiento de Santafé, 1800. Temple sobre papel, 29,2 × 20,4 cm. (Fotografía del Archivo General de Indias (AGI), Ministerio de Cultura y Deporte, Sevilla).

De Sala. 


\title{
Las artes del dibujo, la pintura y el grabado después de las regulaciones de gremios de 1777 y 1790 en Santafé (Bogotá, Colombia)
}

The Art of Drawing, Painting, and Engraving after the Implementation of Guild Regulations in Santafé in 1777 and 1790 (Bogotá, Colombia)

\author{
Laura Liliana Vargas Murcia \\ Instituto Colombiano de Antropología e Historia, Bogotá, Colombia \\ lauralilivm@gmail.com \\ http://orcid.org/0000-0001-8411-3085
}

\section{Resumen}

A finales del siglo XVIII fueron emitidas algunas regulaciones para los oficios en el Virreinato del Nuevo Reino de Granada, que en su mayoría no estaban organizados en gremios. A través de la revisión de fuentes primarias y secundarias se observa la situación de dibujantes, pintores y grabadores en Santafé (Bogotá) luego de las nuevas disposiciones con el fin de observar las repercusiones de las reformas entre artistas y artesanos. Algunas iniciativas como la creación de una escuela de dibujo o la inclusión de las matemáticas dentro de la formación de los artistas no llegaron a consolidarse por completo, otras, como el ingreso de los artesanos a las milicias tuvo cierta

\begin{abstract}
At the end of the 18th century, some regulations regarding crafts and arts were issued in the Viceroyalty of Nueva Granada, though most of these craftsmen were not organized in guilds. In order to analyze the impact that these reforms had on artists and craftsmen, we review documents and secondary sources that reveal the state of drawers, painters, and engravers in Santafé (Bogotá) after the new provisions. Some initiatives were never fully consolidated, such as the creation of a drawing school or the inclusion of mathematics into the artists' training, while others, such as the induction of craftsmen into the militia, were accepted to a certain degree. However, in the case of Santafé, guilds were not
\end{abstract}

Cómo citar este trabajo / How to cite this paper:

Vargas Murcia, Laura Liliana. "Las artes del dibujo, la pintura y el grabado después de las regulaciones de gremios de 1777 y 1790 en Santafé (Bogotá, Colombia)." Atrio. Revista de Historia del Arte, no. 25 (2019): 120-147.

(C) 2019 Laura Liliana Vargas Murcia. Este es un artículo de acceso abierto distribuido bajo los términos de la licencia Creative Commons Attribution-NonCommercial-ShareAlike 4.0. International License (CC BY-NC-SA 4.0). 
aceptación. Sin embargo, en el caso santafereño no se lograron establecer gremios, en el pleno sentido de la palabra, ni se generaron ordenanzas concretas para estos oficios.

Palabras clave: Santafé; Virreinato del Nuevo Reino de Granada; gremios; pintores; dibujantes; grabadores. established - in the full meaning of the word - and ordinances for handicrafts were not generated.

Keywords: Santafé; Viceroyalty of New Kingdom of Granada; guilds; handicrafts; painters; drawers; engravers.

\section{Introducción}

En las últimas décadas del siglo XVIII hubo en España una reflexión en torno a la importancia, reconocimiento, ordenamiento y competitividad de los oficios, lo que se reflejó en el Virreinato del Nuevo Reino de Granada a través de la expedición de la Instrucción general para los gremios de $1777^{1}$ y del Reglamento de los gremios de la plebe para moralizarlos de $1790 .^{2}$

Desde la publicación de los documentos de la Instrucción general por Marta Fajardo de Rueda en la Revista Ensayos, los estudios más relevantes sobre las implicaciones de implantar estos cambios en el sector artesanal neogranadino han sido Cabezas duras y dedos inteligentes. Estilo de vida y cultura técnica de los artesanos colombianos del siglo XIX de Alberto Mayor Mora, ${ }^{3}$ el artículo "La enseñanza de oficios mecánicos en Nueva Granada en vísperas de la Independencia” de Jesús Paniagua Pérez, ${ }^{4}$ mientras que particularmente investigando el ambiente santafereño se debe resaltar el artículo "Control y desorden en Santa Fe de Bogotá (Nueva Granada). En torno a las reformas urbanas de finales del siglo XVIII" de Pilar López Bejarano, ${ }^{5}$ y en cuanto al dibujo en este periodo virreinal, Juan Ricardo Rey Márquez publicó "El dibujo en Nueva Granada en el contexto de las reformas borbónicas.”

A partir de la revisión bibliográfica existente sobre el tema y la búsqueda de fuentes de archivo, el presente artículo pretende analizar el impacto y los alcances que estas normativas tuvieron específicamente sobre las artes del dibujo, la pintura y el grabado en la ciudad de Santafé, capital virreinal, y observar si se experimentó un cambió substancial en el funcionamiento de estos oficios después de estas reformas.

\section{La inexistencia de gremios (excepto el de oribes y plateros)}

A diferencia de lo que sucedía en otras ciudades españolas y americanas, no se encuentran registros en los archivos colombianos de la existencia de gremios ni de ordenanzas en los siglos XVI o XVII en la ciudad

\footnotetext{
1. Marta Fajardo de Rueda, "Instrucción general para los gremios, Santafé, 1777," Ensayos. Historia y Teoría del Arte, no. 1 (1995): 187-215. La revista del Archivo Nacional, no. 10 y no. 11 de 1936 ya había hecho mención a este documento. Ver: Eugenio Barney Cabrera, "Artistas y artesanos," Revista de la Universidad Nacional, no. 12 (1973): 79

2. Díaz de Hoyos, Manuel, reglamenta los gremios de la plebe para moralizarlos, Santafé, 1790, Policía, t. 3, 552r-559v, Archivo General de la Nación (AGN), Bogotá. Transcrito en: Laura Liliana Vargas Murcia, Del pincel al papel: fuentes para el estudio de la pintura en el Nuevo Reino de Granada (1552-1813) (Bogotá: Instituto Colombiano de Antropología e Historia - ICANH, 2012), 374-80.

3. Al respecto ver las reflexiones del primer capítulo "La reorganización de los oficios de cara al siglo XIX" en: Alberto Mayor Mora, Cabezas duras y dedos inteligentes. Estilo de vida y cultura técnica de los artesanos colombianos del siglo XIX (Medellín: Hombre Nuevo Editores, 2003), 15-46.

4. Jesús Paniagua Pérez, "La enseñanza de oficios mecánicos en Nueva Granada en vísperas de la Independencia," Trocadero, no. 24 (2012): 105-24.

5. Pilar López Bejarano, "Control y desorden en Santa Fe de Bogotá (Nueva Granada). En torno a las reformas urbanas de finales del siglo XVIII," BROCAR, no. 30 (2006): 111-37.

6. Juan Ricardo Rey Márquez, "El dibujo en Nueva Granada en el contexto de las reformas borbónicas," Kaypunku 3, no. 2, (2016): $95-116$.
} 
de Santafé. Antes de la Instrucción solamente los oribes y plateros habían utilizado la palabra gremio en documentos oficiales, además de haber tenido reglamentaciones específicas para su oficio en $1631 .^{7}$ Bajo este panorama, luego de la entrada en vigor de la Instrucción general para los gremios lo primero que debía hacerse era precisamente conformar gremios, pues la enseñanza y ejecución de obras de los distintos oficios durante siglos se había ejercido en las casas y oficinas de los maestros, y fuera de los conciertos de aprendizaje y contratos no tenían otras regulaciones. ${ }^{8}$ Sin embargo, son pocos los indicios de logros en la consolidación de estas corporaciones de artistas y artesanos en el Virreinato neogranadino a finales del siglo XVIII y en los últimos años de pertenencia a la Corona en el siglo XIX. Se sabe de la formación de gremios en Popayán en 1777, en Pasto en 1796, la emisión de ordenanzas en Antioquia en 1788 y Cartagena de Indias en 1789. Las noticias más tempranas que se conocen sobre exámenes de conocimiento del oficio de la pintura ya no pertenecen al periodo virreinal, datan de 1819 en la ciudad de Popayán. ${ }^{10}$

Las mencionadas instrucciones, redactadas por Francisco Robledo y Francisco de Iturrate durante el virreinato de Manuel Antonio Flórez, tuvieron la influencia del Discurso sobre el fomento de la industria popular de Pedro Rodríguez Campomanes, ${ }^{11}$ mientras que el Reglamento, redactado por Manuel Díaz de Hoyos, bajo el virreinato de Francisco Antonio Gil Taboada Lemos, observó de cerca la Memoria de Artes y Oficios de la Sociedad Matritense, ${ }^{12}$ y especialmente mostró preocupación por la falta de sujeción de los artesanos a las normas debido principalmente al desorden y a la vagancia. ${ }^{13}$

Entre el final del siglo XVIII y los primeros años del XIX, a pesar de los intentos de normalizar los oficios, el caso de la pintura ofrecía el contrastante panorama de la oficina mutisiana que maravilló por la excelencia de sus láminas y, al mismo tiempo, la obra de pintores que no trascendieron. Al respecto, en 1801, Francisco José de Caldas se quejó del grado de ignorancia en el que se hallaba la pintura, la platería, la herrería y demás oficios del Virreinato, ${ }^{14}$ siendo muy crítico con la situación que veía en Quito. ${ }^{15}$ Y en el caso del oficio del grabado, como veremos más adelante, se concentraba en la Casa de Moneda.

\footnotetext{
7. En 1631, Sancho Girón, marqués de Sofraga, gobernador de Santafé, reglamentó el arte de los plateros para que no enjoyaran sino con oro de veinte quilates. Las menciones al "Gremio de Oribe y Plateros" se encuentran en documentos de mediados del siglo XVIII. Ver: Marta Fajardo de Rueda, "Diccionario de oribes y plateros en la Nueva Granada, siglos XVI, XVII, XVIII y XIX," Ensayos. Historia y teoría del arte, no. 6 (2000): 208-65.

8. Sobre los contratos de aprendizaje y organización de oficinas de pintores en los siglos XVI y XVII ver: "Los maestros del arte de pintura. Noticias incógnitas," en Teatro del Arte Colonial. Primera Jornada, Guillermo Hernández de Alba (Bogotá: Ministerio de Educación, 1938), 13-23; Laura Liliana Vargas Murcia, "Del arte de pintores," en Catálogo Museo Colonial. Vol. 1: Pintura (Bogotá: Ministerio de Cultura, 2016), 67-83.

9. Paniagua Pérez, "La enseñanza de los oficios," 114.

10. Por bando de mayo de 1819 se exigía que los "profesores de cualquier Arte" se registraran en los primeros quince días del mes de junio para presentar un examen público, en el cual se contaría con la presencia del maestro mayor, dos oficiales de su confianza, quienes realizarían un juramento en el acto presidido por el regidor decano, otro regidor más y el procurador síndico, con intervención del escribano del Cabildo para que con los resultados se pudieran despachar los títulos a favor de los que merezcan "abrir oficinas y taller." Los que no dieran muestras de aptitud entrarían en calidad de oficiales bajo la responsabilidad de sus maestros. La prueba de pintura contó con la presencia de los siguientes artesanos: José Antonio Roxas, maestro mayor, Mariano Burbano, maestro y Matías Parmiño, oficial con tienda abierta, quien infortunadamente no pudo demostrar el conocimiento suficiente, por lo que se le prohibía tener aprendices y se le ordenaba que las obras que realizara pasaran por la revisión del maestro mayor. Ver: "Las actas de exámenes de los artesanos de Popayán," Boletín Histórico. Universidad del Cauca. Archivo Central del Cauca, no. 2 (1954): 3-14.

11. Esta publicación debió tener mucha difusión, se encuentra en inventarios de envío desde España a Cartagena. Por ejemplo, en 1778 , Francisco Javier de Blasco embarcó 17 cajones con libros en la fragata "La Diligencia," entre ellos ejemplares de "Industria popular de Campomanes," ver: Registros de ida a Cartagena, Sevilla, 1778-1779, Contratación 1674, leg. 27, Archivo General de Indias (AGI), Sevilla.

12. Real Sociedad Económica Matritense, Memorias de la Sociedad Económica 4 (Madrid: Impreso por Antonio de Sancha, 1787). Este libro contiene un resumen histórico de las actas de la clase de artes y oficios desde julio de 1777 a diciembre de 1779.

13. López Bejarano ubica las Instrucciones dentro del "impulso reformador" y al Reglamento dentro de la "ofensiva reformadora post-comunera." Ver: López Bejarano, "Control y desorden en Santa Fe," 131-32. Ver sobre el efecto del aprendizaje de oficios en la vagancia y la ociosidad: Paniagua Pérez, "La enseñanza de oficios," 108-9. La apreciación de Alberto Mayor Mora a partir de José Celestino Mutis sobre los pintores de Santafé es especialmente negativa, afirmando que "se caracterizaban por su insubordinación, irrespeto, contumancia a las amonestaciones, arrepentimiento fingido, distracción en los juegos, disimulo y baja autoestima." Ver: Mayor Mora, Cabezas duras y dedos inteligentes, 18.

14. Paniagua Pérez, "La enseñanza de oficios," 114. Citando: Correo curioso, no. 40 (1801).

15. Renán Silva, Los ilustrados de la Nueva Granada, 1760-1808. Genealogía de una comunidad de interpretación (Medellín: Banco de la República y EAFIT, 2002), 208-9.
} 
El pago de alcabalas del ramo de artistas y menestrales Para la fecha de expedición del Reglamento de los gremios de la plebe, 1790, el oficio de la pintura junto con el dibujo, la escultura y la arquitectura ya habían sido declarados por cédula real de 1785 como "nobles artes" libres y sin obligación a contribuciones, ${ }^{16} \sin$ embargo, aparecía dentro de los gremios que mandaba organizar el Reglamento junto con los considerados "mecánicos," los cuales eran defendidos en las Memorias madrileñas que tildaban de "ridículo" el descrédito que se les tenía y su menosprecio con respecto a las artes liberales. ${ }^{17}$ Ya en 1783, una real provisión había declarado todos los oficios como honrados y sin limitaciones para el nombramiento en trabajos públicos, aunque su aplicación oficial en América solo se dio a partir de 1805; en la práctica, el desarrollo de la agricultura se consideró primordial y por encima de los oficios mecánicos, pues los reinos americanos debían ser productores de materias primas, y España debía venderles sus manufacturas. ${ }^{18}$ En el punto 37 de las reglas de 1777 se advertía que entre los oficios no había ni la menor diferencia dada por la materia de su trabajo, ni los artesanos eran de peor o más baja condición entre ellos. ${ }^{19}$ Alberto Mayor Mora ha resaltado la importancia que tenía "elevar la autoestima del artesanado criollo" y "la estimación del público en función a favor de la comunidad" en este intento de transformación de los oficios. ${ }^{20}$

La relación jurada de cuentas de alcabalas de don Juan Díaz de Herrera, administrador principal de las Reales Rentas de Alcabala y Armada de Barlovento de Santafé de Bogotá, entre los años 1776 a 1785, daba cuenta del "Ramo de artistas y menestrales" ${ }^{21}$ y aclaraba que el cobro equivalía al $2 \%$ sobre el precio de venta, según lo indicaban la Recopilación de Leyes de Indias en su título 13, libro $8 .{ }^{22}$ Este mismo porcentaje lo corrobora el Real Decreto e Instrucción General de Rentas Reales dentro de su ítem "Géneros del Reyno al dos por ciento" en el cual se especificaba que es la cantidad a pagar por "la venta de tejidos y manufacturas del Reyno que se hace en este pueblo, así en tiendas de vecinos estantes como por transeúntes." 23 Este registro de pago de alcabalas muestra que no todos los oficios tenían esta obligación pues solamente aparecen los recaudos provenientes de las oficinas de batihojas, boticas, tenerías, sastrerías y cererías, apareciendo el nombre de los recaudadores y el dinero recogido, pero no el nombre de los artesanos de cuyas oficinas o tiendas provenía el impuesto. ${ }^{24}$ El pago de alcabala obedecía a una obligación celebrada entre la Administración General y los dueños de tiendas, para lo cual se revisaban los libros de conciertos del año corriente que contenía las partes por menor, registrados bajo una relación jurada. ${ }^{25}$

El cobro de la alcabala en Santafé se efectuaba también sobre efectos de Castilla y de la tierra, pulperías, tiendas de mercader, carnicerías, hacendados, ventas de fincas, imposiciones de censos, almonedas

\footnotetext{
16. Julián Gállego, El pintor, de artesano a artista (Granada: Universidad de Granada, 1976), 200.

17. "Memoria anónima baxo el nombre de Don Antonio Filántropo, sobre el modo de fomentar entre los labradores de Galicia las fábricas de curtidos. Leida en junta general de 7 de diciembre de 1782," en Real Sociedad Económica Matritense, Memorias de la Sociedad Económica, 7-8.

18. Paniagua Pérez, "La enseñanza de oficios," 107-9.

19. Fajardo de Rueda, "Instrucción general," 198.

20. Mayor Mora, Cabezas duras y dedos inteligentes, 22-23.

21. Cuentas de alcabalas, Santafé, 1776-1775, Santa_Fe, 804, pliegos no. 11 de cada año, Archivo General de Indias (AGI), Sevilla.

22. Recopilación de las Leyes de los Reynos de Las Indias. Mandadas imprimir, y publicar por la Magestad Católica del rey Don Carlos II Nuestro Señor (Madrid: Ivlian de Paredes, 1681; México: Facsimilar de Miguel Ángel Porrúa, 1987), título 13, ley 14, 67: "Que se pague a dos por ciento de alcavala y también de la coca." 23. Real Decreto e Instrucción General de Rentas Reales (Barcelona: Imprenta de Antonio Brusi, 1816).

24. Los receptores del derecho de alcabala del ramo de artistas y menestrales de Santafé de 1776 a 1785 fueron: oficina de batihoja: Maestro Josef Joachim Machado y Francisco Lozada; oficina de botica: Antonio Borraz, Luis Mondragón y Alexandro Josef Gastelbondo; oficina de tenería: Gregorio Sánchez Manzaneque Jorge Lozano, Dionisio Niño, Antonio Cajigas y Agustín Arguelles; oficina de sastrería: Salvador Domenec; y tienda de cerería: Lorenzo García y Luis Padilla.

25. Libro de la cuenta de alcabala de Santafé de 1788, 1786-1790, Santa_Fe, 805, pliego 11, Archivo General de Indias (AGI), Sevilla. En estos años se recaudó la alcabala de cererías, tenerías y boticas, no aparecen otros oficios.
} 
y en un renglón denominado “de lo eventual." La Recopilación indiana no entraba en el detalle de nombrar cada uno de los oficios que estaban obligados a pagar sino algunos cuantos para dar idea de quiénes debían hacerlo, así, se ordenaba que los plateros pagaran la alcabala de la plata y el oro que compraran para sus obras y las que vendieran, y que los silleros, freneros, y otros oficiales pagaran la alcabala de las sillas, frenos, estribos, espuelas "y todo lo demás que vendieren," así como los pellejeros, guarnicioneros, herradores, zapateros y boticarios "y otros oficiales de lo que vendieren de sus oficios, y artes, qualesquier que sean." 26

Como se observa, ni pintores, ni doradores, ni escultores, ni grabadores pagaban la alcabala, quizá protegidos por la ya nombrada cédula de 1785 que los eximía de estos pagos; pero surge la duda de por qué otros oficios que no se incluían en tal orden tampoco aparecen contribuyendo con dicho impuesto. Es posible que la obligatoriedad del pago hubiera sido en función a las ganancias generadas por los oficios, los cuales corresponderían a los más solicitados por la población: boticas, tenerías, sastrerías y cererías, mientras que el oficio de batihojas tendría especial control por ser el oro su materia prima.

Puede ser que a pesar de las leyes, no fuera fácil exigir y controlar la alcabala a los menestrales debido a que no habiendo gremios plenamente constituidos, los artesanos no llevaban siempre cuadernos de contabilidad como lo ordenaban las citadas instrucciones de 1777, o si llevaban estos libros contables, el juramento sería la única garantía de veracidad de los datos registrados. Muchas veces las obras no se les pagaban a tiempo como dejan ver algunos testamentos de artesanos donde aparecen deudas por obras ya entregadas, una situación que se daba desde el siglo XVI. ${ }^{27}$ Sabemos que a nivel teórico en España hubo defensas de los oficios mecánicos pero a nivel práctico fue necesaria una cédula real para proteger a los artesanos de los abusos que los compradores cometían. En 1784 al Virreinato llegó una cédula real en la que se ordenaba que no se dilataran los pagos a crédito a artesanos o menestrales, jornaleros, criados y acreedores alimentarios, mandando que desde el día de la interpelación judicial corriera la mora y retardación del pago a beneficio de los artesanos y menestrales, y los intereses mercantiles del 6\% para resarcirles el menoscabo que recibían en la demora y para avivar por este medio directamente el pago. Según lo expresaba el rey, en el reino las clases distinguidas y la gente acomodada abusaban "de su prepotencia" para impedir el pago de su deudas, por lo que ningún fuero debía excusar el obedecimiento del real mandato ni la burla de la justicia ordinaria pues estos impagos "cedían la ruina de muchas familias de estos menestrales, y en perjuicio del público, porque no florecían ni prosperaban los oficios." ${ }^{28}$

Otra contemplación con los artesanos se había dado en 1759 cuando el rey ordenó a la Audiencia de Santafé que no se les exigieran gastos ni contribuciones para celebrar las entradas de los virreyes, pero sí conservaron - a voluntad de los artesanos- el deber de hacer los altares el día del Corpus. ${ }^{29}$

\footnotetext{
26. Recopilación de las leyes de los Reynos de Las Indias, título XIII, ley 6, 66: "Que los plateros paguen la alcavala de la plata y el oro;" Ley viii "Que los silleros, freneros, y otros oficiales paguen la alcavala;" ley 9: "Que otros oficiales, y todos los no exceptuados paguen alcavala."

27. Ver testamentos de pintores en: Hernández de Alba, Teatro del arte, 13-23.

28. Real Cédula favoreciendo al gremio de artesanos con motivo de la usura, Santafé, 16 de septiembre de 1784, Archivo Anexo, Grupo I, CO.AGN.SAA-I.27.27.35, Archivo General de la Nación (AGN), Bogotá.

29. Groot utiliza el término "gremio" para narrar lo ocurrido: "los maestros mayores de los gremios se presentaron con un escrito a la Audiencia, pidiendo se declarase que en las entradas de los Excelentísimos Virreyes y otras personas no estaban obligados a hacer loas, saraos, danzas, máscaras y otras demostraciones." Ver: José Manuel Groot, Historia eclesiástica y civil de Nueva Granada (Bogotá: Casa Editorial de M. Rivas, 1890), $2:$ 74-75.
} 


\section{Pintores y doradores, gremios de la plebe}

Ni la Instrucción ni el Reglamento de gremios levantaron la lista al detalle de los oficios que se podían encontrar en una ciudad, ni los dividieron según la nobleza que pudieran tener. El Reglamento de los gremios de la plebe de 1790 nombraba cinco gremios que debían existir y los oficios que los componían: el de plateros (comprendía batihojas de oro y plata, lapidarios, y relojeros. Se aclaraba que estos dos últimos oficios tenían pocos practicantes por lo que no podían formar gremios independientes), el de zapatería (incluía a los talabarteros, curtidores de suela, baquetas, badanas y los beneficiadores de cordobanes), el de pintores (integrado por los que pintaban al óleo, al temple y doradores), el de herradores (a cargo del trabajo de la lata, el plomo, el cobre, el estaño) y el de barberos (que incluía sangradores, peluqueros y amoladores). En ninguna de las dos regulaciones aparecen ordenanzas sobre la elaboración de obras de cada oficio.

Este documento no incluyó aquellos que el punto 26 de la Instrucción para los gremios del 77 consideró "oficios" que no requerían formalidades ni requerían aprendizaje, ni exámenes, y se ejecutaban por pura imitación, siendo estos el de molinero, tahonero, molendero de chocolate, confitero, pastelero y colchonero, recomendando que las mujeres se dedicaran a estos trabajos "pues así quedarán los hombres más desocupados para los que necesitan mayor aplicación, ciencia y trabajo." ${ }^{30}$ Es raro encontrar mujeres pintoras en el Nuevo Reino de Granada —además de la conocida Feliciana Vásquez en el siglo XVII_- pero no debemos descartar su existencia, pues la ausencia de firmas y los pocos conciertos de aprendizaje y obra asentados en notaría han mantenido en el anonimato tanto a mujeres como a hombres. En torno a la fecha de emisión del Reglamento de 1777 encontramos a María Suárez de Bolaños, viuda del pintor Manuel Merchán Cano, quien en una causa mortuoria de 1776, daba a entender que trabajaba con él como pintora en Popayán. ${ }^{31}$

Llama la atención que los oficios de pintor y dorador sí fueran tenidos en cuenta a la hora de hacer las divisiones pero en cambio no aparece el de escultor. Sabemos que sí había escultores en el Virreinato neogranadino pero quizá, como en el caso de los lapidarios y relojeros, no había una cantidad suficiente como para legalizar un gremio. De igual manera, no se hizo alusión al oficio del grabado que para finales del siglo XVIII tuvo algunas manifestaciones, como ya se verá.

En el caso neogranadino, no se han hallado quejas por parte de los pintores o escultores por considerar que sus oficios estuvieran subvalorados o reclamando su liberalidad. La lectura de testamentos, contratos o pleitos demuestran diferentes realidades entre los pintores, desde los que son reconocidos con precios extraordinarios, dueños de bienes muebles e inmuebles, cabezas de ganado y esclavos, hasta los que mueren endeudados o con bastantes deudas por cobrar, o los que también eran amanuenses o que se interesaban por la lectura de tratados del arte, pero también los que reconocían no saber leer ni escribir pero con una formación de tipo oral que les permitió tener el conocimiento suficiente para lograr importantes contratos. Las notorias diferencias económicas entre unos y otros pueden deberse a múltiples factores como las herencias recibidas, las dotes otorgadas, al talento en su arte y a la habilidad de los negocios tanto dentro de sus oficios como en otras inversiones, al cumplimiento de los pagos por parte de sus compradores, en fin, no se puede englobar la situación de todo este conjunto, aunque tampoco resaltan como poseedores de grandes fortunas.

30. Fajardo de Rueda, "Instrucción general," 196.

31. Causa mortuoria del pintor don Manuel Merchán Cano, Popayán, 1772-1776, Judicial Sucesiones, Signatura 10404 (Col. J II-19 SU), 1r-73v, Instituto de Investigaciones Históricas José María Arboleda Llorente-Archivo Central del Cauca (ACC), Popayán. Transcrito en: Vargas Murcia, Del pincel, $348-49,354-55$. 


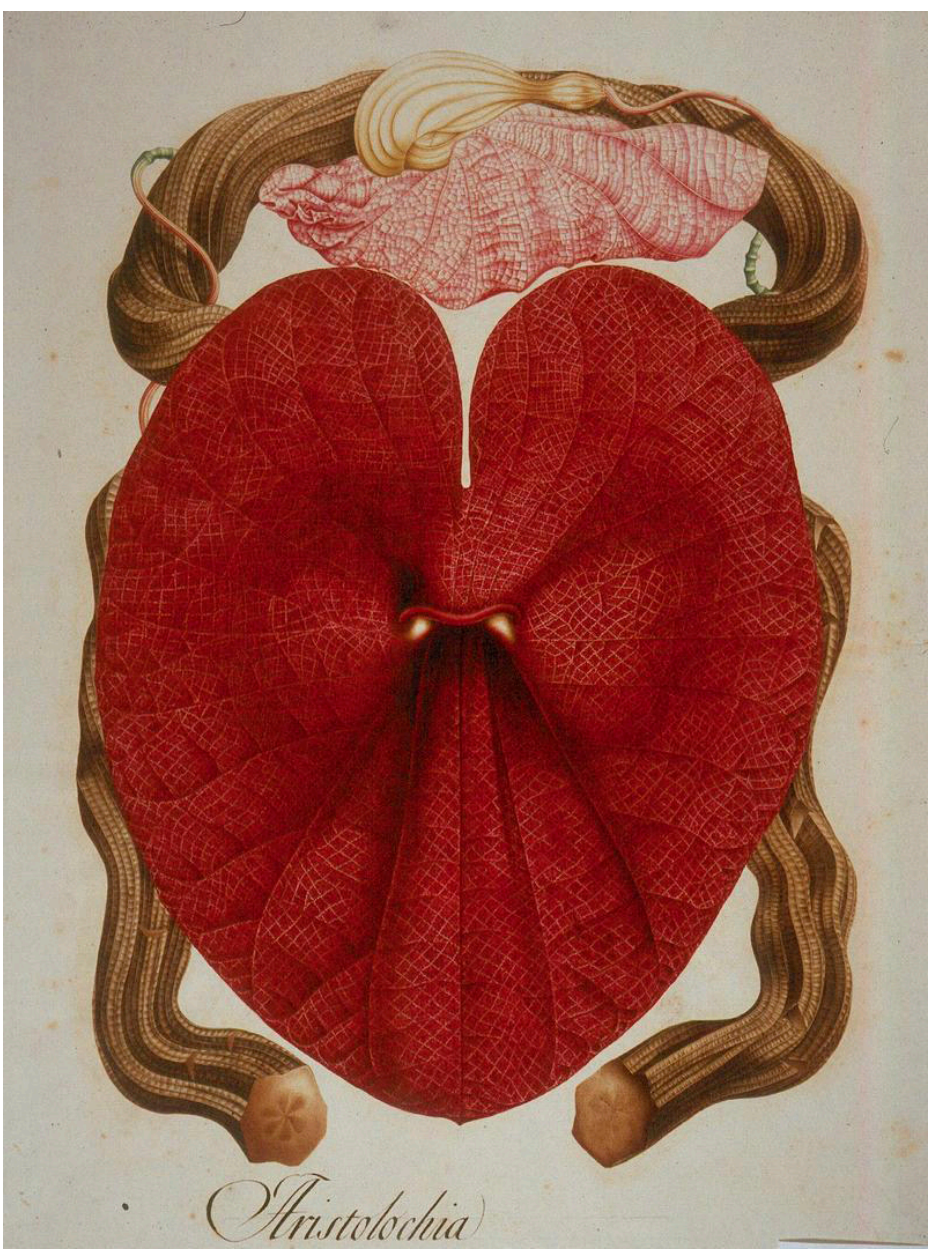

Fig. 2. Anónimo, Aristolochia, 1783-1816. Temple sobre papel, 54 × 37,8 cm. (Fotografía de Flora de la Real Expedición Botánica del Nuevo Reino de Granada, Instituto Colombiano de Antropología e Historia).

La conciencia sobre la nobleza de la pintura parece haberse dado entre los reconocidos artistas que estuvieron encargados en la Expedición Botánica (Fig. 2), ${ }^{32}$ entre los retratistas de virreyes y religiosos y los pintores relacionados con colegios y universidades de la ciudad. ${ }^{33}$ Pero junto a estos, también hubo una cantidad de pintores de quienes apenas conocemos sus nombres por los censos. En general, la relativamente poca aparición en documentos escritos y de firmas en las obras no ha permitido la identificación de artistas con su correspondiente producción. ${ }^{34}$

A lo largo de los siglos coloniales, las firmas en las pinturas y en las esculturas no se encuentran con frecuencia, predomina el anonimato, pero es precisamente en un inventario del año 1785 -año de la cédula que exime a la pintura de obligaciones- cuando se registraron dos pinturas atribuidas a "Vásquez," 35 según dice el manuscrito, al igual que el inventario del pintor Antonio García del Campo, fechado en 1803 , en el cual se registraron "Un San Fernando de mano de Vásquez" y "Otro de San Francisco de Asís de la misma mano," 36 lo que sugiere un reconocimiento ligado al prestigio y calidad de la obra de Gregorio Vásquez, algo que no había sucedido en ningún inventario a esas fechas entre el repertorio conocido hasta hoy día, sobre todo, teniendo en cuenta que el pintor había fallecido en 1711.

Para la redacción del Reglamento, Díaz de Hoyos manifestó haber invitado a su casa "sujetos de cada gremio" — sin dar sus nombres_ quienes aceptaron de buen modo el documento, afirmación que nos per-

\footnotetext{
32. José Antonio Amaya y Beatriz González, "Pintores, aprendices y alumnos de la Expedición Botánica," Credencial Historia, no. 74, 1996, https://www.banrepcultural.org/biblioteca-virtual/credencial-historia/numero-74/pintores-aprendices-y-alumnos-de-la-expedicion-botanica

33. Al respecto, se recomienda consultar el estudio de la pintura del siglo XVIII en cuanto a series de franciscanos y cuadros de defensas de tesis en: Lina del Castillo, María del Rosario Leal y Grace McCormick, Iconografía intelectual en el Virreinato de la Nueva Granada siglo XVIII (Bogotá: Universidad Externado de Colombia, 2013).

34. Los manuscritos notariales y judiciales de momentos posteriores a la emisión del Reglamento de los gremios han conservado nombres como el del pintor y dorador José Antonio Arguello en Girón, el pintor Miguel Estrella en Túquerres y Popayán y el del dorador Francisco García en Santafé. Ver: Vargas Murcia, Del pincel, 367-68, 408-17

35. Inventario que Luis Ortega y Padilla entrega a Juan Martín Zereso, Santafé, 1785, Notaría 1, vol. 211, rollo 43, fotog. 321, Archivo General de la Nación (AGN), Bogotá.

36. Gabriel Giraldo Jaramillo, "Visita al taller de un pintor de la época colonial," Boletín del Museo de Arte Colonial 1, no. 12 (1961): 6.
} 
mite plantearnos dos preguntas: ¿ ¿Al representante del oficio de la pintura no le supuso problema alguno que su arte estuviera al nivel del resto de menestrales? ¿Al usar la palabra gremio, como si ya existieran, se refería más a un conjunto de personas que tenían en común un oficio que a un colectivo de artesanos regidos por unas ordenanzas?

La Instrucción contenía artículos que revelan la desigualdad en la formación que se podía encontrar de un taller a otro. Por ejemplo, en lo concerniente a que todos los artesanos debían saber leer y escribir, o la obligación de conocer tratados correspondientes a su arte, actividades y prácticas que se supondría estarían entre lo básico que se haría en una oficina, ${ }^{37}$ pero según los testamentos de los maestros y oficiales no siempre contaban con estos libros. La situación podía ser muy dispar: mientras en 1813 el pintor de la Expedición Botánica, Pablo Antonio García, poseía entre sus bienes libros escritos por Juan de Arfe, Francisco Pacheco, Celedonio de Arce y Cacho, Christiano Rieger, Atanasio Genaro Brizguz, Giuseppe Galli Bibiena, Gaspar de Molina y Saldívar, Parrasio Tébano, Ramón Pascual Díez, Antonio Rafael Mengs, Diego Antonio Rejón de Silva y Juan Interián de Ayala, además de publicaciones religiosas y otras áreas del conocimiento como geometría o aritmética, y obviamente botánica, ${ }^{38}$ en otros casos, los pintores ni siquiera registraban un solo libro. Se sabe que a bibliotecas de civiles en Santafé llegaron publicaciones relacionadas con el arte pictórico, tales como El arte de la pintura de Leonardo Da Vinci, libro que se anunciaba para la venta en el periódico Correo curioso de $1801 ;{ }^{39}$ este mismo título, con láminas y estampado se vendía en la tienda de José González Llorente, según inventario notarial del 20 de febrero de $1819 .{ }^{40}$

La observación de la calidad de las obras de fines del XVIII y de comienzos del XIX, el renombre de algunos pintores frente al anonimato de otros y los inventarios testamentarios nos hacen pensar en la desigualdad que había en cuanto a la formación, y en la preocupación por el reconocimiento como artistas. Es de suponer que en muchos obradores la enseñanza se transmitiera de manera oral, por la observación directa del maestro y de obras, y a través de la práctica, por lo que el analfabetismo no fue un impedimento para el aprendizaje de los oficios.

La Instrucción general para los gremios fue enfática en la implantación del estudio del dibujo y las matemáticas para una completa formación de los artistas y artesanos; y aunque el caso de la oficina de la Expedición Botánica fue excepcional, el nombrado testamento de Pablo García nos ofrece títulos que pudieron ser consultados por los artistas para acercarse a los números, tales como: "Dorado contador" (Dorado contador. Aritmética especulativa y práctica de Miguel Jerónimo de Santa Cruz); "Aritmética por un padre capuchino" (podría tratarse de Aritmética teórica y práctica de fray Fermín de los Arcos); ${ }^{42}$ "Antorcha aritmé-

\footnotetext{
37. En el caso de la pintura, el término oficina aparece en los documentos coloniales haciendo referencia al espacio en donde el artista o artesano labora. También es usual encontrar solamente la referencia a la casa del maestro. Mientras el termino obrador, utilizado en España, rara vez es usado dentro del contexto de los pintores neogranadinos. Al respecto ver: Vargas Murcia, "Del arte de pintores," 67-83. A finales del siglo XVIII y principios del XIX la palabra oficina se continúa utilizando como puede verse en los manuscritos relacionados con la Expedición Botánica y en las Guías de forasteros, a la vez que aparece con mayor frecuencia la denominación taller en los textos de este periodo.

38. Inventario de bienes de Pablo Antonio García, Santafé, 1813 Notaría 1, vol. 231, ff. 195r-197r, Archivo General de la Nación (AGN), Bogotá. Transcripción en: Vargas Murcia, Del pincel, 426-30.

39. Silva, Los ilustrados, 242-43. Citando: Correo Curioso, no. 24 y no. 26 (1801)

40. Según infografía del Museo de la Independencia - Casa del Florero, Bogotá.

41. Miguel Jerónimo de Santa Cruz, Dorado contador. Aritmética especulativa y práctica: Contiene la fineza y reglas de contar oro y plata, y los aneages de Flandes por moderno y compendioso estilo (Madrid: Imprenta de Don Benito Cano, 1794).

42. Fray Fermín de los Arcos, Aritmética teórica y práctica, en compendio de las cuentas más usuales y corrientes, tanto para el comercio de los Reynos de Castilla, Aragón, Valencia, Navarra, y Mallorca, como para fuera de él (Madrid: Imprenta y librería de Alfonso López, 1786).
} 
tica" (Antorcha aritmética práctica, provechosa para tratantes y mercaderes de Juan Antonio Taboada y Ulloa). ${ }^{43}$ Estos títulos sugieren una formación para las tareas contables del taller y el desarrollo de la habilidad en el cálculo del cambio de moneda y de las equivalencias en oro y plata. El área de las matemáticas que tenía una aplicación directa en las artes era la geometría, de la cual García poseía el libro "Geometría práctica italiana" (quizá Practica Geometriae de Leonardo de Pisa o "Fibonacci”). No se debe olvidar que precisamente Mutis llegó a Santafé en 1762 con la idea de dictar matemáticas y física en el Colegio del Rosario, aunque los dominicos no estuvieron muy de acuerdo con la implantación de estas asignaturas, pues consideraron que muchos de los autores seguidos eran protestantes. En 1774, las reformas de Antonio Moreno y Escandón incluyeron estas ciencias dentro de las cátedras dictadas en Santafé, pero la aceptación de estas no fue pronta, en 1780 el virrey Antonio Caballero le solicitaba al rey que en el Colegio del Rosario se impartiera matemáticas, y solo hasta 1787 Mutis redactó un plan de estudios de esta materia. ${ }^{44}$ Es de suponer que si en el ámbito universitario se presentó esta demora en la enseñanza de las matemáticas, los artesanos tuvieron aún más dificultades para formarse en esta área.

La preocupación por la enseñanza del dibujo tuvo su expresión en la propuesta de creación de una escuela pública de dibujo, canto y música dirigida por el canónigo Francisco Felipe del Campo y Rivas en 1795. Se pretendía fundar una academia llamada "San Felipe Benicio," en la cual dictarían clases Pablo Antonio García, Sebastián Méndez y Joseph María Garzón. ${ }^{45}$ El reglamento, fechado en enero de 1795, no contiene las asignaturas que se cursarían, se centra en la descripción de espacios básicos que tendría la casa, las tareas del portero y del criado, los pagos por parte de los discípulos según su capacidad económica, los fondos que aportarían a esta causa civiles y religiosos de Santafé (la fábrica de la catedral, las tres parroquias de la ciudad, los conventos y monasterios de religiosos excepto los Capuchinos y los de San Diego, el Colegio de San Bartolomé y el Rosario, el Cabildo Secular, padres de familia, el comercio y hacendados, subrayando que a los artesanos se les debe obligar a aportar "puesto que no pueden ser completos sus oficios sin el auxilio del dibujo" $\left.{ }^{46}\right)$, la posibilidad de otorgar premios a los alumnos más consagrados y las actividades permitidas en los ratos libres, entre otros temas.

Pedro María Ibáñez registró la existencia de una escuela gratuita de dibujo surgida de la Expedición, recordando entre sus alumnos a Anselmo García de Tejada, Antonio Gravete y Soto, José Luciano de Elhuyar y Bastida, José María Escallón, Jorge Miguel Lozano, José Remigio Sánchez de Tejada, Pedro José Sánchez de Tejada, Mariano Sánchez de Tejada y Manuel María Álvarez, bajo la dirección de Salvador Rizo. ${ }^{47}$ Aunque estos nombres pertenecen a jóvenes notables dentro de la sociedad, este centro educativo

\footnotetext{
43. Juan Antonio Taboada y Ulloa, Antorcha aritmética práctica, provechosa para tratantes y mercaderes. Instruye á los principiantes con Reglas del Arte Menor, y muchas breves para reducir las Monedas de Castilla unas en otras. Declara modo seguro de comerciar con dichas monedas, la cobranza de vales, y letras de todas partes, y otras curiosidades (Madrid: Impresa por Ramón Ruiz, 1795).

44. Julio Gaitán Bohórquez, "Agenda ilustrada y agenda republicana en la cuestión educativa neogranadina," Rhela, no. 14 (2010): 100-24.

45. La transcripción del "Primer reglamento. Constituciones, distribución de horas y conducta que se debe observar en la Nueva Academia de Bellas Artes. A saber: Pintura, dibujo, música y canto; tanto relativas a los maestros y discípulos y a los subalternos de la casa: cuanto al público y a las personas de él que entren a la casa, ya sea para aprender algún ramo de éstas, ya sea por recreación y curiosidad" puede encontrarse en: Guillermo Hernández de Alba, Documentos para la historia de la educación en Colombia (Bogotá, Patronato Colombiano de Artes y Ciencias - Colegio Máximo de las Academias Colombianas, 1983), 349-54. Este autor ubicó el cuadernillo que contiene este reglamento en el Jardín Botánico de Madrid entre los documentos de José Celestino Mutis. Este dato del proyecto de la academia también es citado por: Rey Márquez, "El dibujo en Nueva Granada," 107. Y en: Juan Ricardo Rey Márquez y Carolina Vanegas Carrasco, Noticias iluminadas: Arte e identidad en el siglo XIX (Bogotá: Alcaldía Mayor de Bogotá, Fundación Gilberto Alzate Avendaño, 2011 ), 16.

46. Hernández de Alba, Documentos para la historia, 353. El reglamento escrito por el canónigo Campo y Rivas daba una interesante instrucción acerca de las imágenes a poner en la academia: "El día dichoso que se haya de comenzar esta grande obra se colocará en la casa con la solemnidad que se pueda, una efigie de Christo, en un salón, otra de María Santísima en el segundo y otra de San Felipe Benicio en el tercero, tomándole por Titular Patrono y Protector de las Artes," en: Hernández de Alba, 352.

47. Pedro María Ibáñez, Memorias para la historia de la medicina en Santafé de Bogotá (Bogotá: Fundación Editorial Epígrafe, 2006), 24; Armando Martínez Garnica
} 
surgió en momentos en los que la formación en un oficio podía ser una manera de reconducción de niños abandonados, pobres y vagabundos, que en la práctica significó la fundación de casas de hospicios durante los virreinatos de Messía de la Cerda y Moreno y Escandón. ${ }^{48}$ Marta Fajardo de Rueda publicó la lista de niños, hallada en un documento del Jardín Botánico madrileño, que entre 1798 y 1799 hicieron parte de esta escuela que funcionó en una casa llamada "La Botánica," algunos de ellos llegaron a ser ilustradores de la Expedición. Igualmente, la profesora Fajardo señala el dato de un manuscrito desaparecido pero que indica el interés de estos pintores por dejar testimonio de sus conocimientos, se trata de "Experimentos prácticos para la miniatura, nuevas composiciones de colores para la imitación del reino vejetal, inventado en la Real Expedición Botánica del Nuevo Reyno de Granada para su flora," firmado por Salvador Rizo en 1804 y que fue propiedad de Miguel Antonio Caro. ${ }^{49}$

En 1801, tuvo su apertura la "Es-

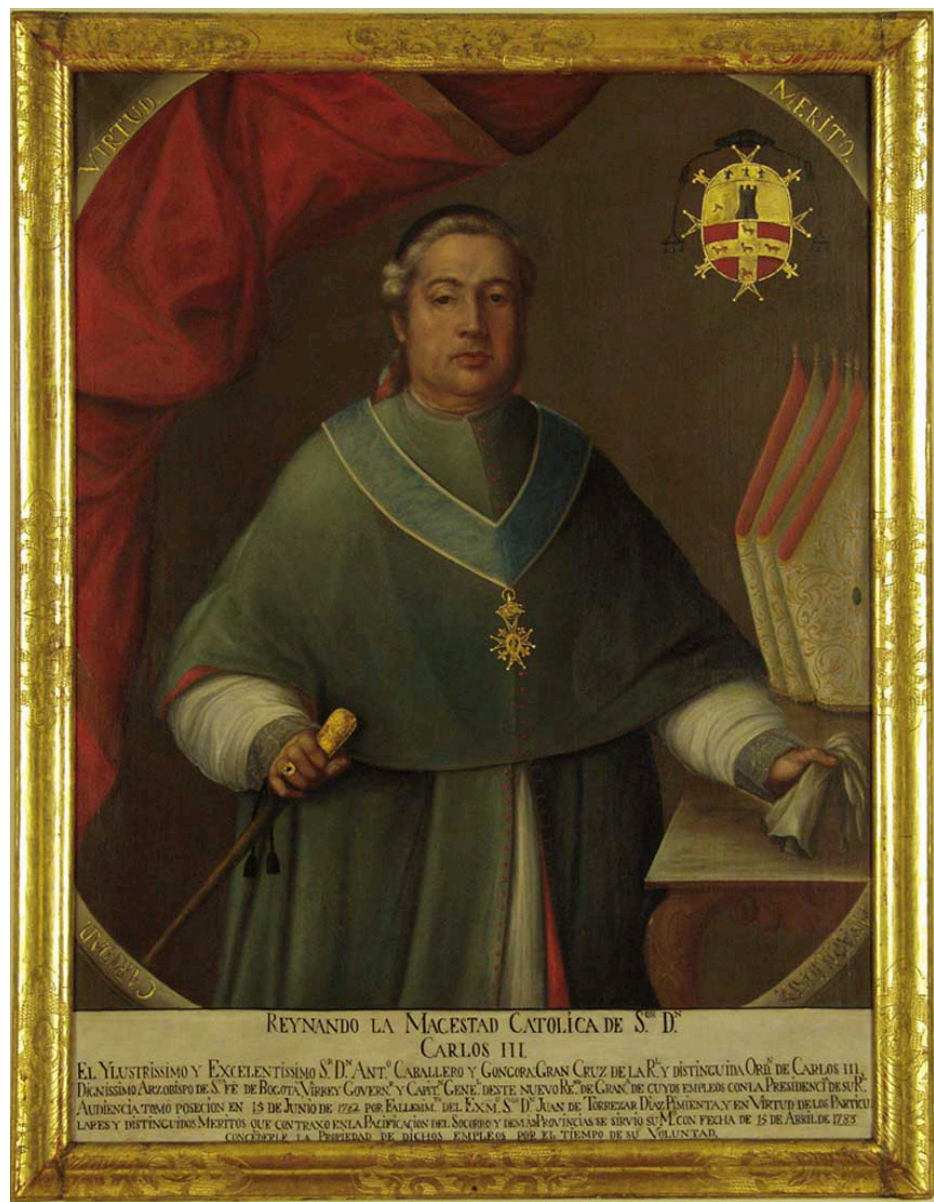

Fig. 3. Antonio García del Campo, Virrey Antonio Caballero, posterior a 1783. Óleo sobre tela. (Fotografía del Museo de Arte Colonial - Ministerio de Cultura, República de Colombia). cuela de dibujo y arquitectura" del ingeniero y matemático Bernardo Anillo, que al parecer no funcionó mucho tiempo pero que contó con ilustres alumnos como Benedicto Domínguez, Francisco Urquinaona, Juan Estévez, Luciano D’Elhuyar y los hijos del marqués de San Jorge. ${ }^{50}$ Pero este interés no fue exclusivo de Santafé, José Ignacio de Pombo comunicó a Mutis en 1806 la aceptación de la Junta del Consulado Real de Cartagena de Indias para establecer una escuela de dibujo, otra de pilotaje y una de matemáticas. ${ }^{51}$

Las características excepcionales de la Expedición Botánica merecen un estudio aparte por lo que solo haremos mención a algunas repercusiones fuera de su círculo de pintores. En cuanto a la enseñanza del dibujo en el Nuevo Reino de Granada, el impacto de este proyecto fue más allá de la recibida por los

y Daniel Gutiérrez Ardila (eds.), Quién es quién en 1810. Guía de forasteros del Virreinato de Santafé para el primer semestre de 1810 (Banco de la República, Biblioteca Luis Ángel Arango Virtual, 2010), http://babel.banrepcultural.org/cdm/ref/collection/p17054coll10/id/0

48. Paniagua Pérez, "La enseñanza de oficios," 116.

49. Marta Fajardo de Rueda, "La obra artística de la Real Expedición Botánica del Nuevo Reino de Granada en el siglo XVIII, 1783-1816," Ensayos. Historia y teoría del arte, no. 1 (1993-1994): 115-16.

50. Silva, Los ilustrados, 450-51.

51. Silva, 135-36. 


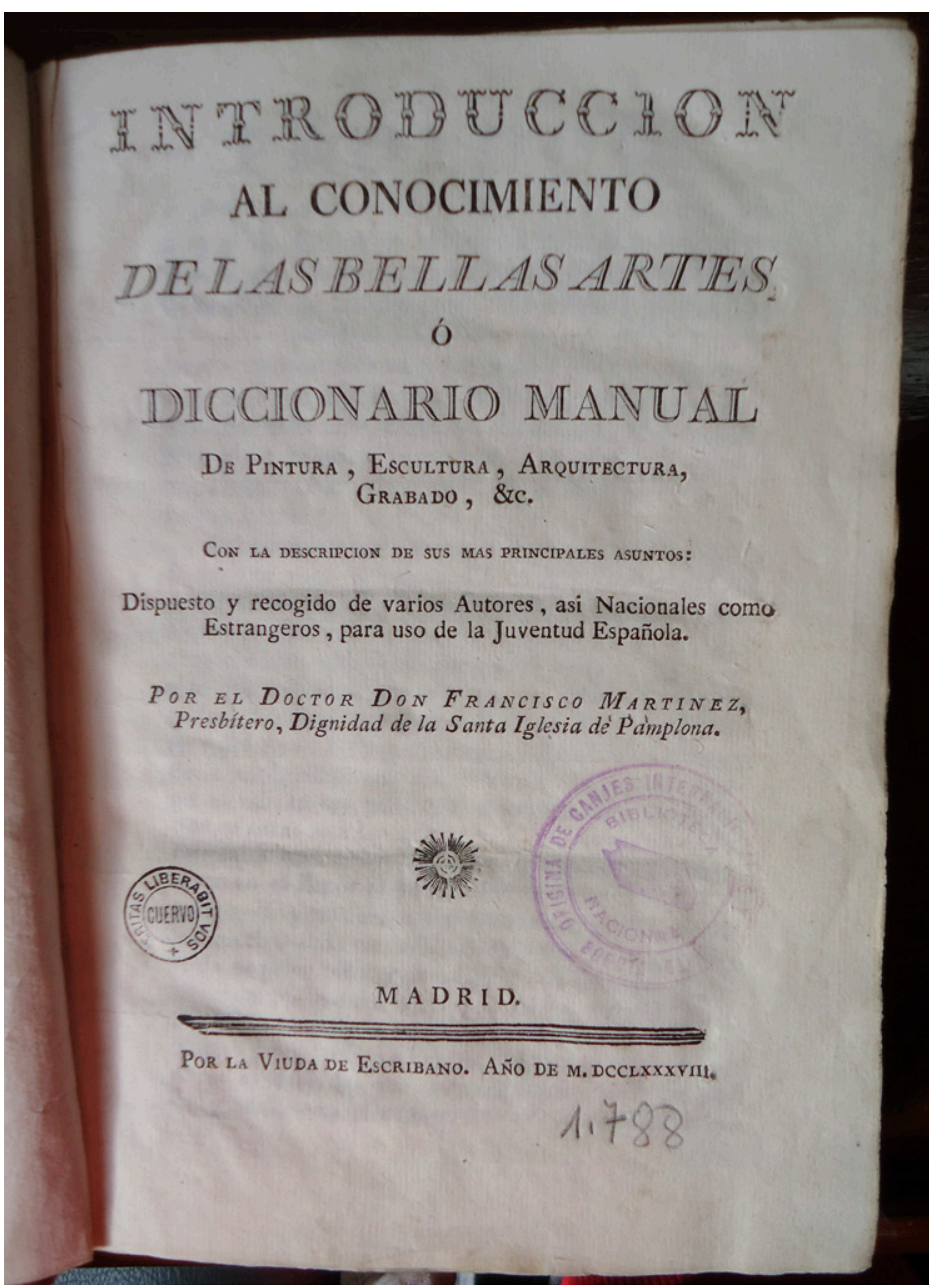

Fig. 4. Francisco Martínez. Introducción al conocimiento de las Bellas Artes. Madrid: Imprenta Viuda de Escribano, 1788. (Fotografía de la Biblioteca Nacional de Colombia). discípulos directos de Mutis, ya que algunos de ellos se convirtieron en maestros y transmitieron el conocimiento que tenían sobre técnicas, tratados, libros ilustrados, observación del natural y posiblemente el uso de pigmentos naturales experimentados por ellos mismos. Se debe recordar que en el momento de emisión de las Instrucciones del 77, en el punto 53 correspondiente a la enseñanza del dibujo, se aclaraba que con dificultad se encontraría a alguien en el Nuevo Reino que supiera dominar este arte, ${ }^{52}$ luego, los pintores botánicos, los arquitectos e ingenieros serían de los pocos que podrían haberse convertido en maestros del área.

La necesidad de aprender dibujo no se pensaba como exclusiva de los gremios artesanales, el virrey Antonio Caballero y Góngora resaltaba la importancia de esta cátedra en la universidad pública que se pretendía fundar, y junto con las primeras letras serían las bases para que los estudiantes aprendieran las demás ciencias (Fig. 3); ${ }^{53}$ el buen dibujo no solamente era necesario para los pintores o para los proyectos artesanales, era básico para los levantamientos topográficos, para el diseño de máquinas, para la arquitectura y la ingeniería civil y militar. Sin embargo, a pesar de los esfuerzos, con el paso del tiempo seguían siendo muchos de los dibujantes formados por Mutis los más capacitados para atender las necesidades oficiales. Entre 1818 y 1820, Mariano Hinojosa, Manuel Martínez, Francisco Villarroel, Lino José Acero, Joaquín Pérez y Antonio Barrionuevo, agregados al ramo de la geografía del Estado mayor, recibieron de los ministros del tesoro público pagos por las copias y construcción de planos geográficos. ${ }^{54}$

En cuanto a la formación de pintores, no se conocen ordenanzas ni antes ni después de las dos regulaciones mencionadas, así como tampoco se conocen tratados escritos en el territorio de lo que sería la actual Colombia. En 1788, el español Francisco Martínez D’Acosta, presbítero en Santafé, en 1798, y en Cusco, ${ }^{55}$ publicó en Madrid el libro Introducción al conocimiento de las Bellas Artes o Diccionario manual de pintura,

52. Fajardo de Rueda, "Instrucción general," 201.

53. Silva, Los ilustrados, 67-68.

54. Comprobantes, Santafé, 1818-1820, Historia: SAA-1.17,27, D.76, ff. 550r-560r, Archivo General de la Nación (AGN), Bogotá

55. Gabriel Giraldo Jaramillo, La miniatura, la pintura y el grabado en Colombia (Bogotá: Instituto Colombiano de Cultura, 1980), $276-80$. 
escultura, arquitectura y grabado con la descripción de varios autores, asi nacionales como extranjeros para el uso de la juventud española. ${ }^{56}$ (Fig. 4) Martínez fue miembro de honor de la Real Academia de San Fernando en Madrid y colaborador en el Papel periódico de Santa Fe de Bogotá, por lo que debió tener influencia sobre los ilustrados santafereños, ${ }^{57}$ y quizá sobre algunos de los pintores con formación más selecta. ${ }^{58}$

\section{Los pintores en las milicias de artesanos de Santafé}

Los censos de la milicia de artesanos de Santafé levantados en 1783 hacen mención a los siguientes oficios: pulpero, escribiente, cantero, zapatero, albañil, sastre, carpintero, platero, barbero, herrero, tejero, peluquero, fundidor, sombrerero, amanuense, cerero, cohetero, talabartero, tintorero, adobero, panadero, curtidor, fresadero, tejedor, locero, molinero, enfardelador, lapidario, cordonero, boticario, farolero, maderero, pintor y dorador; además de otros que no producían manufacturas, tales como: tratante, estudiante, mercader, músico, peón, hortelano, leñatero, truquero, comerciante, ingeniero, tasador y maestro de escuela $;^{59} \sin$ olvidar que también se le permitió la entrada a la milicia a hombres sin trabajo, catalogados en las listas como "vagos." ${ }^{60}$ Para el caso de Santafé, tampoco aparecían los oficios de escultura ni de grabado.

Respecto a los vagos, en la segunda mitad del siglo XVIII, el cura Basilio Vicente de Oviedo llamó la atención sobre la falta de voluntad que tenían los hombres santafereños en aprender algún oficio: "para cualquier ministerio son muy hábiles los ingenios de los naturales de Santafé y de casi todos los hombres del Nuevo Reino de Granada; pero reina en él tan de asiento la desidia o la pereza, que por ella no se aplican, los que viven en los lugares, es (hablo de la gente más ordinaria) a tratantes, mercaderes o pulperos; muy pocos se aplican a la pintura y escultura, y por ello hay tanta falta de ello, a plateros, carpinteros, albañiles, y así de las demás artes mecánicas." ${ }^{1}$

Dentro de las milicias de artesanos de Cartagena de Indias se han destacado las figuras de los pintores Casimiro Jinete y Pablo Caballero Pimentel, cuya trascendencia, desde el punto de vista artístico, militar, político y social, dentro de su condición de milicianos pardos y morenos, ha sido estudiada por Sergio Paolo Solano y Roicer Flórez. ${ }^{62}$ El listado de artesanos milicianos de Santafé activos en 1783 es una fuente que

56. Francisco Martínez, Introducción al conocimiento de las Bellas Artes o Diccionario manual de pintura, escultura, arquitectura y grabado con la descripción de varios autores, así nacionales como extranjeros para el uso de la juventud española (Madrid: Imprenta Viuda del escribano, 1788).

57. Juan Ricardo Rey Márquez, "Sobre el concepto de gusto en el Prontuario Artístico de Francisco Martínez D'Acosta: un capítulo olvidado de la estética iberoamericana," Boletín de Estética 6, no. 15 (2010-2011): 31-63.

58. Gabriel Giraldo supuso que el ítem "un tomo de Martínez" entre los bienes del pintor Antonio García se refería a este libro de Francisco Martínez. Ver: Giraldo Jaramillo, "Visita al taller de un pintor," 8.

59. Lista de los individuos de milicias de Santafé, patria de cada uno de ellos, su estado civil, su domicilio con el nombre de la calle en que lo tenían, Santafé, 1783, Milicias y Marina, SC. 37.18.13, ff. 51r-71r, Archivo General de la Nación (AGN), Bogotá.

60. Tanto el documento de 1777 como el de 1790 expresan la preocupación por la proliferación de la vagancia, especialmente entre los más jóvenes. Es recurrente encontrar documentación con órdenes a los muchachos ociosos y dedicados al juego, chicherías, tabernas y paseos para que se dediquen a la labranza o a "aprehender algún oficio." Algunos de estos muchachos eran enviados al servicio de las armas y otros a las obras públicas. Ver: Expediente levantado por los alcaldes de Tocaima y Mariquita, para enviar al señor Comandante de las armas a los vagos; a fin de que los coloque en el servicio de tropa, Tocaima y Mariquita, 1781-1782, Real Audiencia Cundinamarca: SC.50,1,D.9, ff. 575r, 576v, 581v, Archivo General de la Nación (AGN), Bogotá. Y: Nicolás Alejandro González Quintero, "Se evita que de vagos pasen a delincuentes: Santafé como una ciudad peligrosa (1750-1808)," Anuario Colombiano de Historia Social y de la Cultura 37, no. 2 (2010): 17-44.

61. Yolanda Pachón Acero, Caracterización técnica de la escultura policromada en la Nueva Granada (Bogotá: Universidad Externado de Colombia, 2017), 83. Citando a: Basilio Vicente de Oviedo, Cualidades y riquezas del Nuevo Reino de Granada (Bogotá: Imprenta Nacional, 1930 ), 88.

62. Sergio Paolo Solano D., "Entre pinceles y armas. Pablo Caballero Pimentel, pintor y capitán de Milicias pardas en Cartagena de Indias, siglo XVIII," Amauta, no. 20 (2012): 25-59; Sergio Paolo Solano D. y Roicer Flórez Bolívar, "'Artilleros pardos y morenos artistas': artesanos, raza, milicias y reconocimiento social en el Nuevo Reino de Granada, 1770-1812," Historia Crítica, no. 48 (2012): 11-37. 
nos revela el nombre de varios pintores y doradores, ${ }^{63}$ desconocidos por la historiografía del arte. Hasta el momento no se han hallado obras firmadas pero conociendo ahora sus identidades sería posible en un futuro seguir la pista de estos artistas:

- Víctor Candia, dorador, oriundo de Santafé, 23 años, vivía en la calle Nave de San Joseph e integrante de la Octava Compañía.

- Pedro Candia, dorador, nacido en Santafé, 39 años, su casa estaba ubicada en la calle San Pedro Alcántara y hacía parte de la Octava Compañía.

- José Joaquín Hernández, pintor, natural de Chiquinquirá, 27 años, vivía en la calle del Ciprés y pertenecía a la Séptima Compañía.

- Joseph Antonio Reyes, dorador, 39 años, vivía en los arrabales de la ciudad de Santafé y era uno de los individuos de la Sexta Compañía.

- Phelipe González, dorador, 28 años, tenía su casa en la calle de San Diego y formaba parte de la Sexta Compañía.

- Bernardino Velasco, pintor, nació en Santafé, 37 años, habitaba en la calle de Las Nieves y era parte de la Séptima Compañía.

- Cruz García Roxas, dorador, nacido en Santafé, 38 años, vivía en la calle de Las Nieves y era integrante de la Séptima Compañía.

- Bernardo Vergara, pintor, oriundo de Santafé, 37 años, establecido en la calle de Las Nieves y era miliciano de la Séptima Compañía.

- Josef Antonio Tacorena, dorador, santafereño, 31 años, vivía en la calle del Prado y pertenecía a la Compañía de Granaderos.

- Manuel Parada, pintor, oriundo de Tunja, 35 años, su casa estaba en la calle de Las Cruces y estuvo dentro de la Tercera Compañía.

- Roque Altusarra, pintor, tunjano, 30 años, habitaba en la calle de La Moneda y hacía parte de la Primera Compañía.

Por el contrario, sí encontramos un nombre famoso en un censo sin fecha (ca. 1797) en el barrio de Las Nieves de Santafé: Pedro Figueroa, quien contaba con cuatro discípulos en la casa no. 16 de la calle Santa Ana. ${ }^{64}$

Un detalle a observar es que los pintores se encuentran dispersos por diferentes calles, que al parecer era algo corriente pues a diferencia de los plateros que tendían a concentrarse en las actuales carreras $5 .^{\mathrm{a}}$, 6. ${ }^{\mathrm{a}}$ y $7 .^{\mathrm{a}}$ entre calles 13 y 12 , que actualmente sigue siendo una zona de joyerías, los artesanos no se agrupaban en sectores de la ciudad. Este hecho fue notado por el capitán de milicias don Manuel Díaz de Hoyos quien prefería que las numerosas chicherías del centro de Santafé fueran reemplazadas por establecimientos de artesanos. ${ }^{65}$

\footnotetext{
63. Lista de los individuos de milicias de Santafé, Santafé, 1783, Milicias y Marina: SC. 37.18.13, ff. 55v, 56r, 57rv, 59rv, 61r, 68v, 70v, Archivo General de la Nación (AGN), Bogotá.

64. Censo en Santafé, Milicias y Marina: SC.37.141.6, S/F, Ff. 151-162, Archivo General de la Nación (AGN), Bogotá. Agradezco al historiador Sergio Paolo Solano por indicarme la referencia de este documento.

65. "Tabernas. Los enunciados daños no tienen todos juntos comparación con los que causan las asesorías de chicherías en el centro de la ciudad, como lo he representado al Gobierno en virtud de habérseme comisionado, para que retirándolas a calles más excusadas se pusieren en las que ocupan, con orden de los Gremios de Artesanos, que viven dispersos en los barrios y son tan menesterosos por sus oficios cuanto son de daño las chicherías, lo mismo encontrará V. E. en la producción de cualesquiera vecino de honor en hablando del porte de estas gentes, todos están hostigados con su cercana vecindad." En: Disposiciones para la administración de Santafé, Santafé, 1789, Diversos-Colecciones, 31, N. 91, ff. 4rv, Archivo Histórico Nacional (AHN), Madrid.
} 
Este censo de milicias de 1783 deja en Santafé el registro de cinco pintores y seis doradores, que sumados a algunos más que podrían no haberse interesado en entrar a este cuerpo y, dejando de lado los pintores de la oficina de Mutis, no suman el número de integrantes que por ejemplo tenía el gremio de sastres en 1807. Esta corporación alcanzó a tener más de 50 personas entre maestros y oficiales, según se indicó en la solicitud de aprobación al fiscal civil de la ciudad para adquirir un arca triclave, ${ }^{66}$ obedeciendo así a uno de los puntos de la Instrucción general para los gremios de 1777. En Pasto, la cantidad de pintores barnizadores sí reuniría a un número importante de artistas para conformar un gremio, del cual se tiene noticias a finales del siglo XVIII; ${ }^{67}$ y aunque se incluían en el renglón de pintores, la técnica del barniz de Pasto es diferente a la del pincel pues se usa la resina de mopa-mopa pero sus acabados recuerdan la policromía de una escultura. ${ }^{68}$

Quizás, entre los pintores que no recibían encargos oficiales, esa búsqueda de reconocimiento social no se dio desde la defensa teórica de la nobleza de su oficio sino a través de su ingreso a los cuerpos militares. Las milicias de artesanos de Santafé apoyaron la defensa a los avances comuneros pero, como sucedió en otros lugares, las quejas sobre su altivez no se hicieron esperar, y así consta en el Reglamento para la plebe, cuyo punto 7 destaca la "soberbia" que tenían ante los alcaldes ordinarios y los maestros. ${ }^{69}$ Junto con la de Cartagena de Indias y la de Santafé, encontramos la milicia de artesanos de Barbacoas, en este caso creada por la importancia de la ciudad como centro minero aurífero, de la que también hubo quejas por el fuero militar que cobijaba los juicios de sus artesanos en lugar del fuero civil. ${ }^{70}$ Sin embargo, la búsqueda de status a través de la milicia no fue fácil para los artesanos, pues no contaban con vestuario ni armamento suficiente, ni tenían una instrucción compleja, lo que transmitía un carácter marginal ${ }^{71}$ estas características y las obligaciones militares, a la par de la necesidad de seguir trabajando en los oficios, produjeron una imagen poco atractiva para su vinculación, ${ }^{72}$ además de que en el caso santafereño se sintió una especie de rechazo popular por parte de la población recelosa y temerosa de las inmunidades que tenían los milicianos, además de que al interior del cuerpo militar se sentían discriminaciones raciales y de clase. ${ }^{73}$

\footnotetext{
66. Santafé: gremio de sastres solicita arca guardar ahorros, Santafé, 1807-1808, Miscelánea: SC.39,3,D.13., ff. 263r- 268v, Archivo General de la Nación (AGN), Bogotá.

67. María Fernanda Duque, "Legislación gremial y prácticas sociales: los artesanos de Pasto (1796-1850)," Historia Crítica, no. 25 (2003): $115-36$.

68. José Rafael Sañudo, Apuntes sobre la historia de Pasto. La Colonia bajo la Casa de Borbón (Pasto: Imprenta La Nariñense, 1940), 132; María del Pilar López Pérez, "El barniz de Pasto. Encuentro entre tradiciones locales y foráneas que han dado identidad a la región andina del sur de Colombia," en Patrimonio cultural e identidad (Madrid: Ministerio de Cultura de España, 2007), 225-34; María del Pilar López Pérez, "Quito, entre lo prehispánico y lo colonial. El arte del barniz de Pasto," en Arte quiteño más allá de Quito (Quito: Fondo de Salvamento del Patrimonio Cultural de Quito FONSAL, 2007), 44-63. Ver: Juicio ejecutivo por pinturas de barniz de Pasto, Popayán, 1738, transcrito en: Vargas Murcia, Del pincel, $27-91$.

69. López Bejarano, "Control y desorden en Santa Fe," 134.

70. En 1785 Nicolás Antonio de Vivanco, Teniente Gobernador, Justicia Mayor y Oficial Real, sentó una queja sobre las dos compañías formadas cada una por cien hombres mercaderes o artesanos en la ciudad de Barbacoas por "el errado concepto de que gozan fuero militar" y por lo tanto no obedecían a la justicia ordinaria, estando muchos de ellos "llenos de vicios y recargados de deudas" y además, negándose a trabajar en sus oficios aunque les pagaran; uno de tales vicios era el juego de dados que se llevaba a cabo en tiendas de pulpería y por el cual fue arrestado el miliciano Ramón Ortega, natural de Túquerres y trabajador en minas, cuyos superiores pensaban que a este individuo sí le correspondía ser juzgado por el fuero militar por ser soldado. La misma situación se había presentado en las milicias de la ciudad de Pasto. En su defensa, los milicianos alegaban que gracias a ellos, los montes se hallaban con menos delincuentes y además suprimían "la soberbia y el orgullo de los negros esclavos" que laboraban en las minas, reduciéndolos a una templanza humilde y a una servidumbre subordinada. Estas compañías seguían el mismo reglamento que regía en Cuba, por lo que los reos de estas milicias debían ser juzgados por la justicia militar, lo que al parecer causaba malestar a la ordinaria. López Moreno, Manuel: Juez y Alcalde de Barbacoas. Su competencia de jurisdicción con Manuel Díaz del Castillo, capitán-comandante, por el conocimiento de causas del personal de milicianos, formado de mercaderes y artesanos, para los cuales pedía dicho comandante la jurisdicción castrense, Barbacoas, 1785, Competencias: SC,13,4,D.1, ff. 1r-78v, Archivo General de la Nación (AGN), Bogotá. Y ver: Reglamento para las milicias de infantería y caballería de la Isla de Cuba: Aprobado por S. M. (Lima: Imprenta de la Real Casa de los Niños Expósitos, 1793).

71. Juan Marchena Fernández, Ejército y milicias en el mundo colonial americano (Madrid: Editorial Mapfre, 1992 ), 190.

72. Sobre las actividades que se llevaban a cabo en las milicias ver el capítulo "La vida de la guarnición y la vida cotidiana de las ciudades" en: Marchena Fernández, 211-44.

73. Mauricio Puentes Cala, "Milicianos y milicias en la Provincia de Santa Fe: Una vista desde el sector subordinado (1781-1788)," Cambios y permanencias, no. 3
} (2012): 446-47, 459 
Es probable que los dibujos de los uniformes de las milicias que se conservan en el Archivo General de Indias fueran hechos por pintores incorporados a ellas. Se trata de 24 pinturas, fechadas en 1785, 1804 y 1810, correspondientes a: uniforme de gala solicitado por el Ayuntamiento de Santafé (Fig. 1), infantería auxiliar del Nuevo Reino de Granada, infantería de Cartagena, voluntarios blancos de Cartagena, artilleros milicianos pardos y morenos de Cartagena, artilleros veteranos de Cartagena, milicias pardas de Cartagena, milicias todos los colores de Mompox, milicias de Popayán, tropa veterana de Popayán, infantería provincial de Santafé, regimiento fijo de Santafé, caballería de Santafé y uniforme diario del Ayuntamiento de Santafé, uniforme del Tribunal de Cuentas. ${ }^{74}$

\section{El grabado, un oficio escaso y privilegiado}

A diferencia de otros lugares de América, en el Nuevo Reino de Granada no se instalaron talleres completamente dedicados al grabado, así que tuvieron que importarse desde Europa, encontrándose en los registros de la Carrera de Indias la llegada de estampas desde lo que hoy sería Espańa, Italia, Alemania, Francia y Bélgica. En México (1539), Lima (1584) y Guatemala (1660) sí surgieron tempranamente talleres de imprenta que estuvieron ligados a la creación de grabados para ilustrar publicaciones.

La primera casa de impresión en el Virreinato de la Nueva Granada fue la imprenta de la Compañía de Jesús, que parece haberse puesto en funcionamiento entre 1735 y 1736, seguida por las imprentas cartageneras de José Rioja y Antonio Espinosa de los Monteros. Precisamente, el Reglamento para las milicias de infantería, y caballería de la Isla de Cuba, que era usado para las milicias además de otros reglamentos, ${ }^{75}$ fue impreso en 1781 en Santafé por la imprenta de Espinosa de los Monteros. ${ }^{76}$ Se podría suponer que los grabados de pequeño formato que acompañaban a los textos eran realizados dentro de las mismas imprentas para ser montados junto con los textos formados por tipos móviles, mientras que en los libros importados desde Europa se encontraban estampas realizadas por encargo a talleres de grabado que entregaban sus planchas a la imprenta. La instalación de aquellas primeras imprentas neogranadinas no supuso el desarrollo del oficio del grabado para ilustrar libros pues sobre todo se trataba de pequeños ornamentos. ${ }^{77}$

El trabajo oficial de los grabadores españoles dentro de la Casa de Moneda representa un renglón aparte de los artistas y artesanos debido a las condiciones propias de su formación y nombramiento desde la península para luego trasladarse a las cecas americanas. En lo relativo a Santafé, durante muchos años, se pensó que las primeras planchas abiertas en el Virreinato de la Nueva Granada databan de 1782, de autoría del grabador español de la Casa de Moneda, Francisco Benito. ${ }^{78}$ Según Gabriel Giraldo Jaramillo, el primer

\footnotetext{
74. Ver las imágenes en: Archivo General de Indias (AGI), MP-Uniformes. Y en: Gumersindo Caballero Gómez, Juan Marchena Fernández, y Diego Torres Arriaza, El ejército de América antes de la Independencia: ejército regular y milicias americanas, 1750-1815; hojas de servicio, uniformes y estudio histórico (Madrid: Fundación Mapfre Tavera, 2005), CD.

75. Marchena Fernández, Ejercito y milicias, 204-5.

76. Alvaro Garzón Marthá, Historia y catálogo descriptivo de la imprenta en Colombia (1738-1810) (Bogotá: Gatos Gemelos comunicación, 2008), 29, 135-43, 196-98.

77. Para una mirada general sobre las estampas en el Nuevo Reino de Granada ver: María del Pilar López Pérez y Laura Liliana Vargas Murcia, "La estampa en el periodo colonial," en Historia del grabado en Colombia, eds. Centro Cultural y Educativo Español Reyes Católicos y Álvaro Medina (Bogotá: Editorial Planeta Colombiana S.A., 2009), 11-61; Laura Liliana Vargas Murcia, "Aspectos generales de la estampa en el Nuevo Reino de Granada (Siglo XVI - Principios del siglo XIX)," Fronteras de la Historia 14, no. 2 (2009): 256-81.

78. Giraldo Jaramillo, La miniatura, 271-75. Aunque en este libro se cita con los apellidos Benito de Miranda, en las estampas y documentos del Archivo General de Indias solamente aparece como Francisco Benito.
} 
indicio de impresión correspondería a La Divina Pastora (estampa dedicada al virrey y arzobispo Antonio Caballero y Góngora) de la mano de Benito, segundo tallador de esta ceca y originario de Salamanca. Sin embargo, a partir del estudio de Álvaro Garzón Marthá podemos sugerir que las imágenes de un recibo elaborado para las congregaciones del Corazón de Jesús y de la Virgen de Nuestra Señora de los Dolores, fechado el 25 de abril de 1762, corresponderían a uno de los primeros grabados abiertos por el salmantino. Pero no es el único grabado anterior a la fecha propuesta por Giraldo, también lo son: un almanaque titulado Últimos meses del Año del Señor 1778 con los Santos, Fiestas Movibles, y de precepto, que se guardan en este Reyno..., impreso por la Imprenta Real de don Antonio Espinosa de los Monteros y que posee un grabado (no de Benito); y de la misma casa salieron los Almanak, ò Kalendario del Año del Señor de 1780, 1781 y 1782, y los almanaques impresos en 1781 y $1782 .{ }^{79}$ Del mismo Benito existe una estampa de Nuestra Señora del Rosario de Chiquinquirá (Fig. 5), una de las imágenes con mayor devoción en Nueva Granada, difundida sobre todo por la Orden de Predicadores, grabada en 1791, en honor del virrey José de Ezpeleta. A pesar de la ubicación en la historiografía del arte colonial de Francisco Benito como primer grabador en este territorio, existen referencias que hacen suponer que hubo grabadores desde más temprano, aún en el siglo XVII — como sí lo había señalado Guillermo Hernández de Alba— ${ }^{80}$ pues la presencia de planchas metálicas abiertas entre las propiedades de plateros sugieren que estos artistas pudieron incursionar en este arte dada la cercanía de los materiales y la técnica. ${ }^{81}$

Es importante aclarar que el trabajo de grabador en el campo de la numismática se refiere a la talla de metal que tiene como fin la elaboración de monedas, no la impresión por medio del entintado de las planchas. Sin embargo, los principios aprendidos en cuanto al dibujo y manejo de herramientas y soportes tenían muchas similitudes con el de un grabador de matrices para impresión de imágenes. Se sabe de la llegada de otros grabadores a Santafé antes de la época en la cual Francisco Benito estuvo activo como grabador, es el caso de don José Martín Carpintero, condecorado y nombrado "grabador mayor" de la Real Casa de Moneda, según lo afirmó su hermano Eugenio Martín en 1791, al declarar el motivo por el cual se había establecido en América procedente de Castilla. ${ }^{82}$

Tomás Benito, hijo del nombrado Francisco Benito siguió los pasos de su padre, siendo primero aprendiz de tallador, y debido a que se había "dedicado con celo y mucha aplicación a instruirse en el Arte, de modo que tiene acreditado su aprovechamiento" ${ }^{83}$ se propuso en 1776 su nombramiento como oficial segundo de tallador y abridor de la Real Casa de Moneda de Santafé y, más tarde, según aprobación dada en Madrid en 1783, enviada al arzobispo virrey, se aceptaría su ascenso como tallador supernumerario. En estos nombramientos se destacaba la escasez de personas que supieran el arte de la talla sobre metal en el Nuevo Reino de Granada:

\footnotetext{
79. Garzón Marthá, Historia y catálogo, 122, 152, 161-62, 168-69.

80. Hernández de Alba, Teatro del arte, 113.

81. En el siglo XVII, el bachiller Juan Cotrina dejó entre los bienes de su oratorio algunos moldes de estampas. Dado que su padre Juan Cotrina Copete o Topete fue platero y que el bachiller, a decir de las herramientas que poseía, conoció el manejo del buril, surge la duda acerca de si el origen de estas planchas grabadas es europeo y de ser así cómo llegaron a sus manos estas obras, o si pudieron haber sido tallas abiertas por su padre o por él mismo a partir de estampas o cuadros de pintura. Las planchas registradas corresponden a "moldes de estampas" de Nuestra Señora de Chiquinquirá, Nuestra Señora de las Aguas, san Benito Abad, dos rostros de emperadores y otros de romanos. Al respecto ver: Laura Liliana Vargas Murcia, "Estampas europeas en el Nuevo Reino de Granada (siglos XVI-XIX)" (tesis doctoral, Universidad Pablo de Olavide, 2013), 25-26. Citando: Testamentaría del bachiller Juan Cotrina, Santafé, 1680, Notaría 1, ff. 164r-171v, Archivo General de la Nación (AGN), Bogotá.

82. Mortuoria de Eugenio Martín Carpintero, Santafé, 1791, Notaría 1, rollo 43, fotograma 1689, Archivo General de la Nación (AGN), Bogotá.

83. Cartas y expedientes de la Casa de la Moneda 1770-1793, Santafé, 30 de septiembre de 1776, Madrid, 18 de Julio de 1783, Santa_Fe, 830, Archivo General de Indias (AGI), Sevilla.
} 


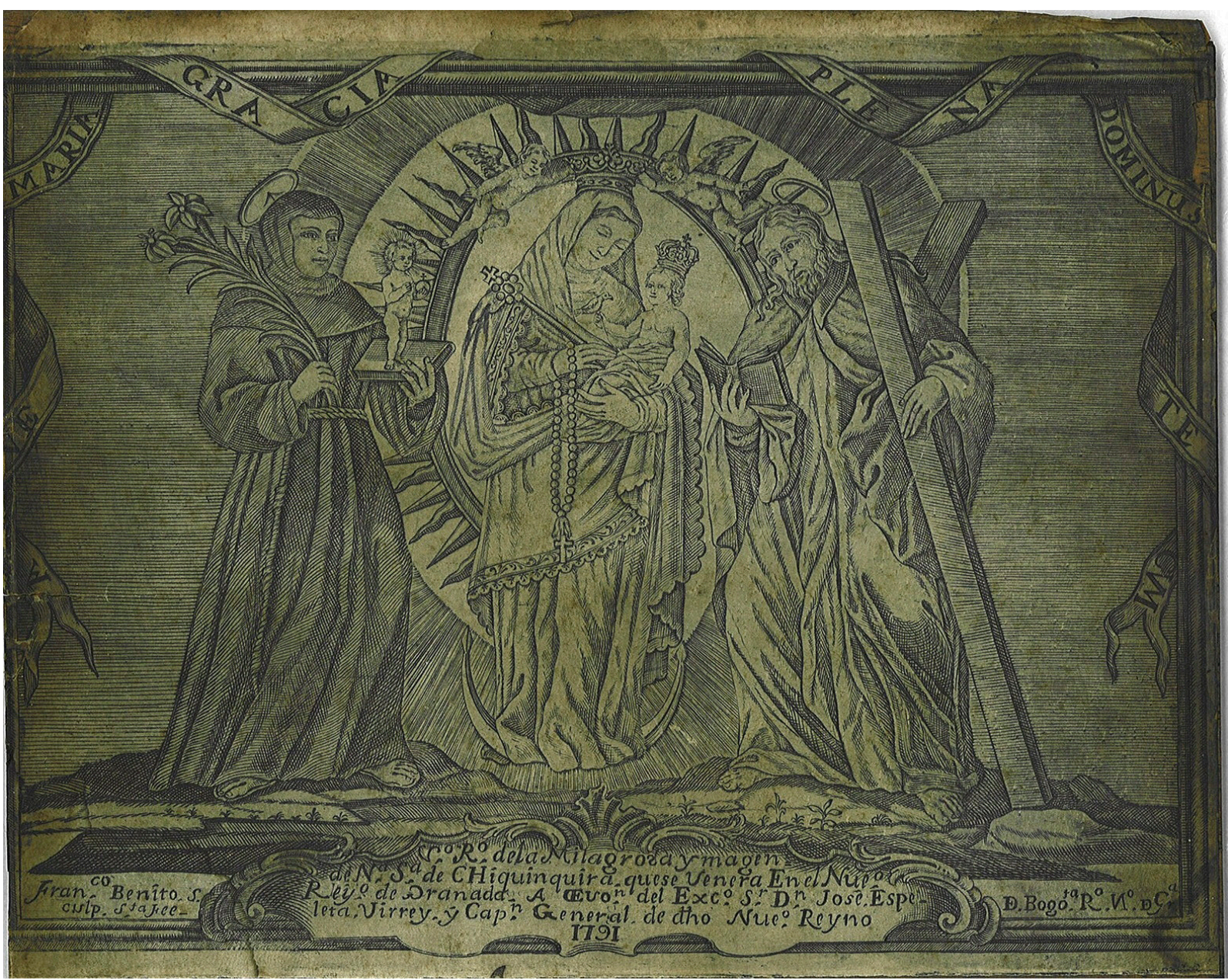

Fig. 5. Francisco Benito, Nuestra Señora de Chiquinquirá, 1791. Estampa sobre papel. Colección particular.

Enterado el Arzobispo Virrey de todo el Expediente, y de que para el desempeño de las obligaciones de Ensayador y Tallador que por enfermedad o muerte de los propietarios, son muy raros los que allí se dedican a esta facultad, y por lo mismo de un crecido costo que vayan de España; ha tenido por conveniente conformándose con el parecer del Fiscal de lo Civil de aquella Real Audiencia, nombrar a don Tomas Benito, por Tallador supernumerario de la expresada Casa de Moneda, con el sueldo anual de cuatrocientos pesos, y lo hace presente para que si fuere del real agrado de V. M. se digne aprobar este nombramiento. ${ }^{84}$

Tomás Benito afirmaba haber sido formado como aprendiz durante ocho años bajo la tutela de don Joseph Carpintero y realizó medallas del escudo y del real retrato para comprobar la calidad de su obra en dibujo y talla, conforme al artículo 31 de las Reales ordenanzas para el gobierno de las Casas de Moneda. Tomás Benito y Prieto apeló a los méritos de su padre Francisco para solicitar su nombramiento, entre los cuales destacó algunas de sus obras que permiten demostrar que además del metal, el funcionario real dominaba la talla en piedra:

84. Cartas y expedientes de la Casa de la Moneda 1770-1793, Santafé, 7 de Noviembre de 1782, Santa_Fe, 830, Archivo General de Indias (AGI), Sevilla. 
Padron hecho en el Aino de 1779) ded numero de Almas que havitan en esta Ciudad dea

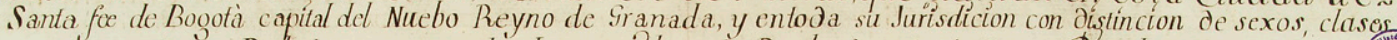

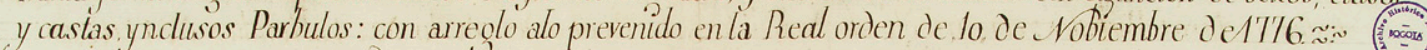

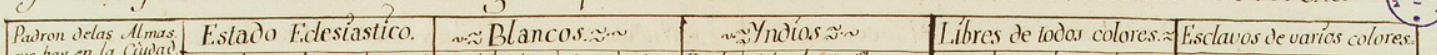

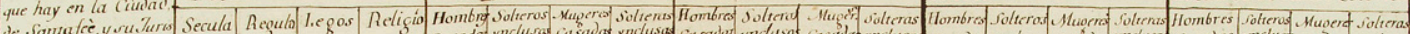

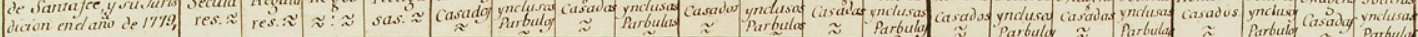

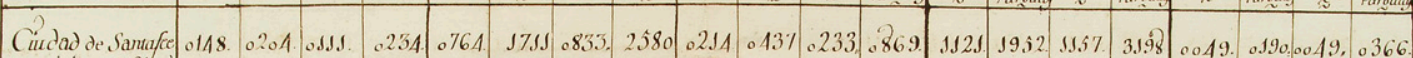

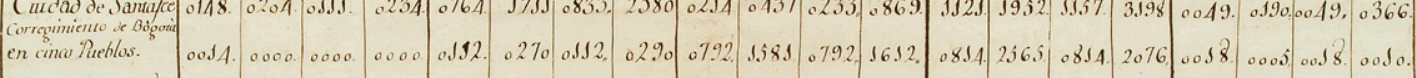

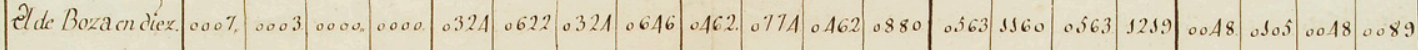

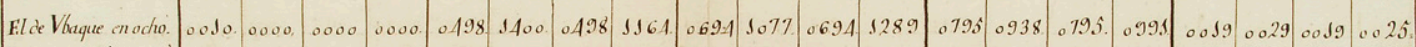
$\begin{aligned} & \text { El de Sipaquira, Vbate } \\ & \text { en diez,y Ocho. }\end{aligned}$
0.25

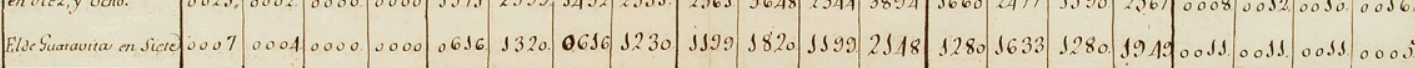

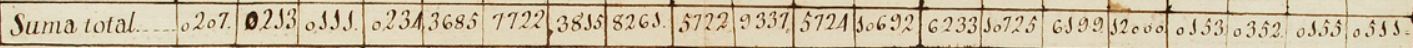

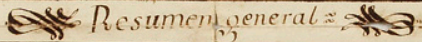

\begin{tabular}{|c|c|c|}
\hline Total de Matrimonios : ง.n & $\begin{array}{l}\text { Total de hombres de rodas Clases, Castas y } \\
\text { cotadow ynd lusos farbulos. }\end{array}$ & $\begin{array}{l}\text { Mugeres de rodos estado y clases yndusa } \\
\text { Parbulas: }\end{array}$ \\
\hline 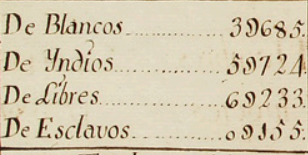 & 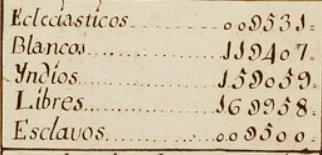 & 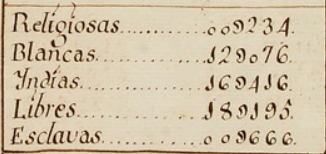 \\
\hline Suma Total ....... Jjs797 & Total de hombres .44 945.3 & Total de Mugeres . $470,587, \approx$ \\
\hline
\end{tabular}

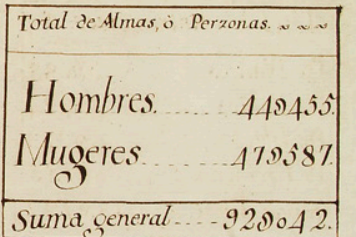

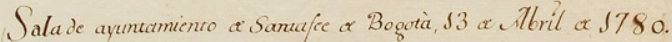
ornangmpuzanos
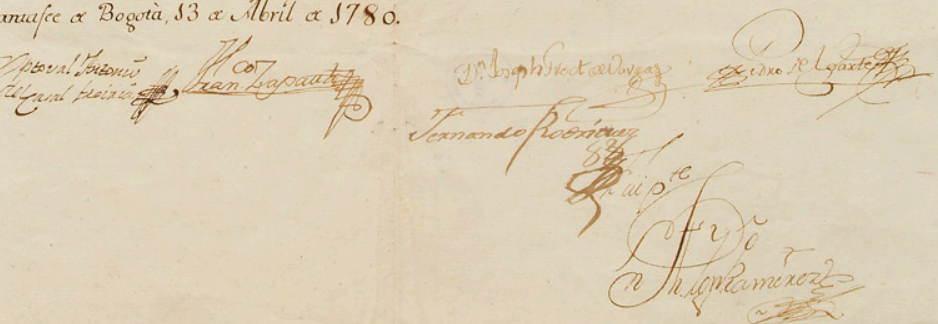

Fig. 6. Padrón de Santafé de Bogotá, 1779. Manuscrito, 50 × 38 cm. Mapas y planos, Mapoteca 4, 698 - A, Archivo General de la Nación (AGN), Bogotá.

la celosa diligencia de mi Padre se ha extendido en beneficio de esta Real Casa en abrir varios escudos de Armas Reales en piedra, para las fachadas de las puertas, y bulto del Rey en medio relieve: cuyas obras están manifiestas a todos y últimamente por orden del Excelentísimo Virrey Don Manuel de Guirior abrió dos retratos de nuestro rey el uno en platina ligada y el otro en platina pura, obra tan singular en su especie que mereció de la real aceptación como se deduce del Real orden expedido, a fin de que fuese premiado. ${ }^{85}$

Luego del fallecimiento de Joseph Carpintero, Anselmo García de Tejada pidió en 1816 a Pablo Morillo el nombramiento como tallador principal de la Real Casa de Moneda de Santafé. Tejada grabó en 1818 la imagen de Nuestra Señora de la Peña con base en la escultura de la ermita del mismo nombre, ${ }^{86}$ lo que demuestra que los funcionarios de la ceca hicieron planchas para imprimir en papel.

Teniendo en cuenta los contextos políticos y administrativos, y las características técnicas del grabado, pueden plantearse algunas hipótesis que podrían explicar la poca y tardía actividad de los grabadores

85. Cartas y expedientes de la Casa de la Moneda, Santafé, 1776, Santa_Fe, 830, carta no. 171, Archivo General de Indias (AGI), Sevilla. 86. Álvaro Medina, Procesos del arte en Colombia 1 (1810-1930) (Bogotá: Universidad de los Andes, 2013), 32-34, 491. 
en el territorio neogranadino: las imprentas que utilizaron estampas para ilustrar los libros se hallaron en las capitales de los virreinatos (México y Lima), ciudades que eran centros administrativos donde se podía ejercer mayor control por parte de la Corona española, mientras que Santafé fue capital del Virreinato de la Nueva Granada en un primer intento de 1717 a 1723, y luego se consolidó en 1739. Por otra parte, hubo un proteccionismo económico de la Corona española hacia la producción de la península y un interés en manejar la exportación de estampas europeas hacia América a través de sus comerciantes. Dado el número de ejemplares que de una plancha se pueden obtener en poco tiempo y la facilidad de su transporte por tratarse de soportes livianos, se debía controlar su difusión, pues podían contener mensajes no aprobados por el Santo Oficio de la Inquisición, las comunidades religiosas o la Corona; era más fácil controlar la salida y la entrada de imágenes en los puertos, que en talleres de grabado, ya que a los lugares de embarque y desembarque se enviaban veedores de la Inquisición que cumplían con la misión de revisar estos materiales, aunque las imprentas también debían contar con un permiso de la Corona. ${ }^{87}$ Existen casos en los que se ordenan requisas a tiendas y almacenes en búsqueda de estampas y pinturas críticas contra Carlos III, especialmente por la expulsión de los jesuitas, y también en búsqueda de material "volteriano." 88

Desde el punto de vista técnico y económico pudieron darse razones que detuvieron el desarrollo del arte del grabado en la Nueva Granada. Una plancha de grabado permite hacer cientos de copias del mismo diseño y su elaboración requiere una dispendiosa labor de dibujo, talla, entintado e impresión. El mercado requería una amplia variedad de estampas que satisficiera la demanda de gustos y especialmente estaba ligada a las devociones. De otro lado, ciudades como Santafé, no alcanzaron en la época colonial la cantidad de población que tenían ciudades como México y Lima, lo que posiblemente no la constituía como un escenario atractivo para la oferta de estas imágenes. El censo de 1779 indica que Santafé contaba con 16.390 habitantes incluyendo hombres, mujeres y niños dentro de las categorías: eclesiásticos, blancos, indios, libres "de todos los colores" y esclavos "de varios colores." ${ }^{99}$ (Fig. 6)

La falta de papel fue un hecho determinante, no solamente para la práctica del grabado sino del dibujo. Se requerían papeles de trapo, especialmente de algodón, que se producían en molinos españoles, que no cubrían la demanda peninsular ni americana y que no alcanzaron la calidad de los genoveses, flamencos y franceses; tan costosos y demorados en llegar de Europa a América que se volvió bien de contrabando, por lo que sus secretos de elaboración eran celosamente guardados. ${ }^{90}$ En cambio, desde 1580 se produjo papel en Culhuacán (México) pero para surtir el mercado novohispano. Tan importante y escaso fue el papel que en 1639 se emitió una cédula real en la que el oficio de hacer papel alcanzaba el nivel de arte y no se le consideraba un oficio mecánico.

La escasez de papel se mantuvo con el paso del tiempo y para finales del XVIII, Mutis no contaba con las cantidades que requería aunque se trataba de un trabajo para la Corona, y así lo constata la carta que envió al virrey Antonio Caballero y Góngora el 1 de febrero de 1785. En la comunicación le expresaba

\footnotetext{
87. Laura Liliana Vargas Murcia, "Religiosas pero prohibidas: Control en la circulación de estampas en el Nuevo Reino de Granada," Ensayos. Historia y teoría del arte 19 , no. 28 (2015): 16-28.

88. Ver: Retención de libros prohibidos y pinturas indecentes a don Francisco Miranda, Madrid, 1782, Inquisición, Cartas desde la Suprema para los Tribunales de Indias, Edición 28, Libro 346, Archivo Histórico Nacional (AHN), Madrid. Y: Ronda que se le practicó a Antonio Crespín en su almacén, con motivo de una estampa y un cuadro del Juicio Final, Cartagena, 1773, Milicias y Marina, t. 128, ff. 644r-661r, Archivo General de la Nación (AGN), Bogotá. Transcritos en: Vargas Murcia, Del pincel, 365, 366, 371

89. Censo de población de la ciudad de Santafé, Santafé, 1779, Mapoteca 698A, Archivo General de la Nación (AGN), Bogotá

90. Gonzalo Gayoso Carreira, Historia del papel en España 1 (Lugo: Servicio de publicaciones Diputación de Lugo, 1994), $17-38$.
} 
su preocupación por la dificultad de encontrar papel de marca mayor de óptima calidad para la elaboración de las láminas que sus dibujantes hacían de las especies estudiadas, por lo que hubo una solicitud del virrey para no gravar este elemento cuando era enviado al sabio. Mutis le contó cómo aprovechando un viaje del comerciante José Valdés a España le encargó 18 resmas de papel dándole una muestra para que supiera el tamaño y la calidad, pero solamente le consiguió cuatro resmas de marca mayor y ocho de menores dimensiones por lo que le pedía al virrey permitir la introducción de este género prohibido para el comercio en el momento en que Valdés se lo llevara. En efecto, por carta del mismo año, Mutis le avisó al comerciante de la llegada del papel al Virreinato. ${ }^{91}$ En 1790 volvió a quejarse de la falta de papel con Juan Jacobo Gahn, cónsul de Suecia en Cádiz, y le pidió interceder para que le fueran enviadas seis resmas de marca mayor de la mejor calidad encajonadas en hoja de lata. ${ }^{92}$

No son muchas las referencias de estampas mexicanas o limeñas en los documentos neogranadinos de los siglos XVI a principios del XIX. A pesar de la distancia, había un predominio de las estampas europeas que llegaban a Cartagena, Portobelo, Santa Marta y Río Hacha.

Esta preferencia pudo tener también sus causas en la diferencia entre las calidades del grabado en Europa y el realizado en América, donde, a pesar de encontrarse bellos ejemplares, no era la generalidad encontrar el nivel de las casas flamencas.

El oficio de grabador en la Corona y sus reinos estaba ligado a la Casa de Moneda, pues era un cargo de nombramiento real y quienes lo dominaban tenían la exclusividad para ejercerlo en esta institución. Los grabadores oficiales eran enviados desde España — con contadas excepciones como la de Tomás Benito y

\footnotetext{
91. Mutis, José Celestino, Archivo epistolar del sabio naturalista don José Celestino Mutis, comp. y con notas de Guillermo Hernández de Alba, t. 1, vol. 3 (Bogotá: Instituto Colombiano de Cultura Hispánica, 1968), 220-21, 238-39.
}

92. Mutis, 28 
Prieto-, y se dedicaron sobre todo a la apertura de moldes para la emisión de moneda. Es posible que muchos secretos del grabado de detalle sobre metal se mantuvieran en reserva al poder ser utilizada esta técnica para la falsificación de monedas. La técnica de grabado sobre metal con punzón y buril era conocida por plateros de oro y plata, pero seguramente no tenían el dominio del dibujo que tenía un grabador de impresos, y sería más rentable el oficio de la platería que el de impresor de grabados.

A comienzos del XIX, las imprentas santafereñas continuaron su producción, especialmente de materiales de tema religioso con sencillas portadas, adornadas en sus laterales por diseños simples. De vez en cuando se encuentran estampas muy sencillas como las que se observan en el Libro de la Cofradía de las Ánimas benditas del Purgatorio o en el formato de nombramientos de la administración de correos donde se observa un escudo puesto a partir de un buen grabado. ${ }^{93}$

A pesar de la aparición de estos grabadores, no hubo obras de calidad, como lo manifestó Francisco José de Caldas en el Semanario no. 3 al afirmar que: "Mucho sentimos que el estado de las Artes no nos permita aclarar las ideas por medio del grabado." ${ }^{4}$ En la misma publicación pero en su ejemplar no. 4 de 1809, José Manuel Campos Cote se quejaba de no poder anexar una carta geográfica y se excusaba afirmando que "sentimos no poderla publicar por falta de grabado..." 95 Este mismo año, Alexander von Humboldt, en "Prospecto a la Geografía de las Plantas" publicado en el Semanario no. 16, escribió:

Sentimos no poder acompañar á esta traducción la lámina interesante, y luminosa que formó el Autor para la inteligencia de esta obra. La falta de planchas y Gravadores nos obligan a suprimirla. Pero conociendo la necesidad de producción, hemos entregado un exemplar al Mtro. D. Antonio García para que calcándolo forme copias exactas. Los que quieran sacar todo el fruto que promete Geografía de las Plantas, pueden ocurrir al dicho García, quien ofrece dar un ejemplar, en papel de marca, por el moderado precio de 2 pesos fuertes. ${ }^{96}$

A juzgar por las imágenes grabadas en las portadas de libros, no hubo una gran destreza en el manejo de este arte en Santafé y Cartagena. Ejemplo de ello es el escudo de Carlos IV que aparece invertido, a manera de espejo y con poco detalle, en la primera página del Reglamento para la conservación de la vacuna en el vireynato [sic] de Santafé: formado por el Exmo. Señor Virey [sic] Don Antonio Amar de orden de S. M. publicado por la Imprenta Real de don Bruno Espinosa de Los Monteros en 1805 (Fig. 7). ${ }^{97}$

Décadas después de la expedición de las regulaciones para los gremios, los santafereños percibían que la situación no había variado mucho y el funcionamiento de los talleres y la calidad de muchas obras no se habían visto beneficiados, como apunta López Bejarano al citar un extracto del Correo Curioso: "Las artes apenas se conocen en este Reino, sin tener otras que las que posee cualquier pueblo miserable, como son malos pintores y peores albañiles, carpinteros y herreros" y la relación de mando de 1803 del virrey Pedro Mendinueta en la que se queja de la ausencia de una policía gremial para el desarrollo de los oficios. ${ }^{98}$

93. Garzón Marthá, Historia y catálogo, 413, 424.

94. Garzón Marthá, 58. Citando: la nota de pie de página no. 19 del Semanario, no. 3 (1808)

95. Garzón Marthá, 58. Citando: Semanario, no. 4 (1809): 26

96. Garzón Marthá, 58. Citando: Semanario, no. 16 (1809).

97. Garzón Marthá, 426.

98. López Bejarano, "Control y desorden en Santa Fe," 136. Citando: Correo Curioso de Santafé de Bogotá, no. 5 y no. 6 (1801). 
El panorama de la escultura tampoco era alentador. Son pocos los nombres de escultores que se conocen en el periodo de las reformas de los oficios en la Nueva Granada. Uno de ellos fue el cartagenero Hermenegildo Ayala, autor del camarín y del retablo del Cristo de la Expiración de la iglesia de Santo Domingo de Cartagena en $1807 .{ }^{99}$ Esta situación se debe a que era un momento de pocos encargos de índole eclesiástico, las iglesias conservaban las obras pictóricas y escultóricas que habían encargado en épocas anteriores, así como las casas de los civiles tenían las obras que habían heredado, recibido por dote o comprado en almonedas, muchos de los bienes muebles pasaban de una generación a otra, disminuyendo así la necesidad de encargos.

La llegada de la Independencia truncó los intentos de cambio, pronto los pintores estarían retratando por encargos oficiales a los próceres, ${ }^{100}$ al igual que los grabadores, como Justo Pastor Lozada, el primer litógrafo colombiano, de cuyas planchas salió una sencilla estampa de

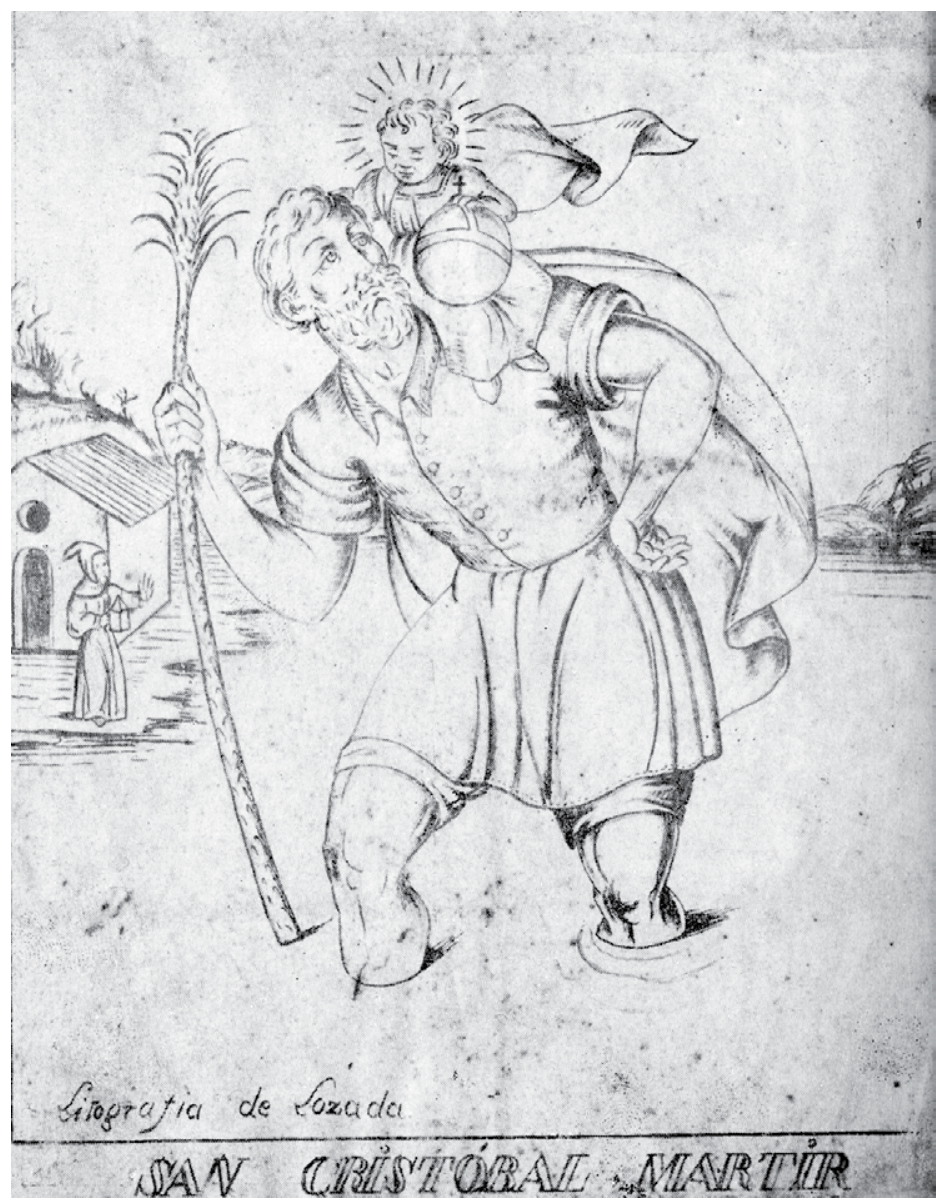

Fig. 8. Justo Pastor Lozada, San Cristóbal Mártir, ca. 1820. (Fotografía de Gabriel Giraldo Jaramillo).

Francisco de Paula Santander, además de estampas religiosas (Fig. 8). ${ }^{101}$ En las primeras décadas de la República se continuó con el incipiente sistema de organización gremial, aunque el número de artesanos activos fue menor y la demanda de obras también se vio afectada por la situación de pobreza dejada por las luchas que se libraron. El declive en la calidad de muchos de los objetos que se produjeron y la nula capacidad de producción en masa, favorecieron la entrada de mercaderías importadas durante el siglo XIX como el mobiliario. ${ }^{102}$ El caso de Santafé no fue único, la misma conclusión de precariedad en los resultados de la aplicación de las Instrucciones se tiene para la provincia de Antioquia. ${ }^{103}$

\footnotetext{
99. Carmen Ortega Ricaurte, Diccionario de artistas en Colombia (Banco de la República, Biblioteca Luis Ángel Arango Virtual, 1965), http://babel.banrepcultural.org/cdm/ref/collection/p17054coll10/id/2732

100. Jaime Santibáñez recibió 32 pesos del tesoro público por valor de los dos retratos que hizo de los señores libertadores, presidente y vicepresidente, en Cali, 26 de septiembre de 1821. El 29 de septiembre de 1821 se le pagó al pintor Carlos Quesadas 32 pesos por dos retratos de los mismos personajes en Archivo General de Indias (AGN), Archivo Anexo, t. 28, f. 140r y 145r.

101. Gabriel Giraldo Jaramillo, El grabado en Colombia (Bogotá: Editorial ABC, 1960).

102. Ver: María del Pilar López Pérez, Museo de la Independencia - Casa del Florero, Más que muebles. Diseño en tiempo de independencias (Bogotá: Ministerio de Cultura de Colombia, 2012),

http://www.museoindependencia.gov.co/que-hacemos/exposiciones/Exposiciones-de-larga-y-corta-duracion/PDF\%20Exposiciones/Mas\%20que\%20muebles.pdf 103. Luis Fernando Franco, "Los artesanos de Antioquia a fines del período colonial: una mirada a través de la Instrucción General para los Gremios de 1777," Historia y Sociedad, no. 26 (2014): 81.
} 
La revisión de obras pictóricas de finales del siglo XVIII y principios del XIX, exceptuado las producidas en la oficina de Mutis y por los pintores de la élite como Joaquín Gutiérrez, no sugiere una mejora en la calidad del dibujo ni de la composición o de la técnica pictórica con respecto a los siglos anteriores.

\section{Conclusiones}

Luego de la expedición de la Instrucción general para los gremios y el Reglamento de los gremios de la plebe, no se encuentran en Santafé indicios de una organización gremial que haya generado ordenanzas y control a través de exámenes, ni una formación más ilustrada en los talleres. La oficina de la Expedición Botánica ha sido el gran paradigma de la ilustración en el arte neogranadino, pero el resto de pintores no tuvieron las facilidades para elevar el conocimiento de su oficio, exceptuando el caso de quienes accedieron a la escuela gratuita de dibujo. Factores como la poca cantidad de artistas para agremiarse, el poco número de maestros calificados, la relativamente baja cantidad de población en la ciudad, la falta de ciertos materiales, la ausencia de escuelas o academias que garantizaran la formación de los aprendices hicieron que el panorama de las artes no cambiara mucho luego de las reformas.

La Corona, además de las normativas escritas en el papel, no ofreció estrategias ni programas a implementar para lograr una formación que cambiara contundentemente la mentalidad y la educación de artistas y artesanos. Las escuelas de dibujo, distintas a la de la Expedición Botánica, surgieron del interés particular de ciertos personajes y no de un proyecto construido por la administración real ni virreinal, y el listado de alumnos deja ver el corto alcance que tuvieron, sobre todo favoreciendo a los jóvenes de familias notables de la ciudad.

La erradicación de la vagancia, el ocio y el vicio entre los menestrales, aún décadas después de la emisión de la Instrucción de 1777 y el Reglamento de 1790, seguía siendo una de las grandes preocupaciones, no solo en Santafé sino en las demás provincias. ${ }^{104}$ Pero además del interés en disminuir la ociosidad y mejorar la producción, se podría pensar en un afán de control de las imágenes que podrían tener un tono satírico o revolucionario contra la monarquía.

La ausencia de escritos teóricos o de instituciones a favor de la defensa y el desarrollo de las artes frente al alistamiento de artistas y artesanos en las milicias de Santafé evidencian una búsqueda de reconocimiento social no a través del intelecto sino del respeto por el uniforme, y la ventaja de ser juzgado por un fuero militar y no civil, aunque como se vio, las condiciones de estos milicianos fueron bastante precarias.

\footnotetext{
104. En 1793, Francisco José de Caldas, ejerciendo como padre de menores del Cabildo de Popayán propuso al gobernador de esta provincia que se promoviera el estudio de "Artes y Oficios, bajo la dirección de maestros artesanos idóneos, para salvar de la ociosidad y de la perdición a los jóvenes nobles y plebeyos de la ciudad," lamentándose de ver "los gremios desiertos y las calles, trucos y garitas, etc., pobladas de jóvenes lozanos" y haciendo una observación en la cual es evidente que aún ejercer oficios manuales es mal visto: "Juzgan que es incompatible la hidalguía con los oficios, y apartando de sí con una mano las artes, con la otra abrazan la pereza e inacción." Ver: Hernández de Alba, Documentos para la historia, 333-43. En 1816, don Vicente Sánchez de Lima, teniente coronel de los Reales Ejércitos, gobernador intendente y comandante general de las provincias de Antioquia y Chocó, ordenó lo siguiente: "Hago saber: que debiéndose desterrar el ocio de los habitantes de las provincias de mi mando, como manantial de los vicios que trastornan el buen orden, oponiéndose a la común felicidad, y considerando que pueda existir en los artistas; para averiguarlo, aplicar el competente remedio, y evitar que con este pretexto quieran libertarse de las pensiones a que de otro modo estarían sujetos; se previene, que todo el que ejerza algún arte, presente semanalmente a este Gobierno lista de las obras que haya hecho denominando los individuos a quien pertenezcan, con apercebimiento [sic] que de lo contrario serán juzgados como vagos, y se les dará el destino correspondiente. Publíquese y circúlese. Dado en Medellín a 4 de septiembre de 1816." En: El Gobernador de Antioquia Vicente de Lima envía comunicación al Virrey de la Nueva Granada Francisco Montalvo, avisándole sobre la publicación de dos bandos impresos, Antioquia, 1816, Historia: SAA-I.17,21,D.50, f. 381r, Archivo General de la Nación (AGN), Bogotá.
} 
La demanda de impresión de imágenes de calidad para periódicos e informes científicos no tuvo una respuesta favorecedora en el desarrollo del oficio del grabado, la Corona no impulsó el envío de grabadores formados en Europa para multiplicar este conocimiento en el Virreinato pues su prioridad fue la producción de matrices para las Casas de Moneda.

Ni desde la Corona ni desde los virreyes y sus funcionarios hubo iniciativas concretas para el mejoramiento de las artes, tal como la creación de una academia o el envío de especialistas en áreas identificadas como claves para el avance de las artes tales como el dibujo o las matemáticas. En general, no se ofrecieron condiciones para el cambio y los artesanos siguieron viviendo - o sobreviviendo- con lo que requería el mercado santafereño. Una de las pocas resoluciones tomadas por parte del rey para mejorar el estado de los oficios artesanales fue la emisión de la cédula real de 1784 para acabar con la práctica generalizada de no pagarles a tiempo las obras contratadas.

La aparición de nombres de pintores en los censos de Santafé, identidades desconocidas hasta la fecha en la historiografía del arte, sugiere que sus obras no se destacaron y no dejaron huella en aquella época, para ser recordados en los primeros escritos sobre el arte anterior a la República. Y las obras que han merecido un reconocimiento hacen parte de la pintura de personajes de élite que ocupan importantes cargos civiles y religiosos dentro de "una incipiente corte virreinal." 105

\section{Referencias}

\section{Fuentes documentales}

Archivo General de Indias (AGI). Sevilla. Fondos: Santa_Fe, Contratación y MP-Uniformes.

Archivo General de la Nación (AGN). Bogotá. Sección Colonia, Fondos: Archivo Anexo, Competencias, Miscelánea, Milicias y Marina, Real Audiencia Cundinamarca, Historia, Mapoteca y Protocolos notariales.

Archivo Histórico Nacional (AHN). Madrid. Fondos: Diversos - Colecciones e Inquisición.

Instituto de Investigaciones Históricas José María Arboleda Llorente - Archivo Central del Cauca (ACC). Popayán. Fondo: Judicial Sucesiones.

\section{Fuentes bibliográficas}

Amaya, José Antonio, y Beatriz González. "Los pintores de la Expedición Botánica." Credencial Historia, no. 74 (1996).

https://www.banrepcultural.org/biblioteca-virtual/credencial-historia/numero-74/pintores-aprendices-y-alumnos-de-la-expedicion-botanica

Arcos, Fray Fermín de los. Aritmética teórica y práctica, en compendio de las cuentas más usuales y corrientes, tanto para el comercio de los Reynos de Castilla, Aragón, Valencia, Navarra, y Mallorca, como para fuera de él. Madrid: Imprenta y librería de Alfonso López, 1786.

Barney Cabrera, Eugenio. “Artistas y artesanos.” Revista de la Universidad Nacional, no. 12 (1973): 69-82. Borja Gómez, Jaime Humberto. "La tradición colonial y la pintura del siglo XIX en Colombia." Análisis.

105. Al respecto ver: Jaime Humberto Borja Gómez, "La tradición colonial y la pintura del siglo XIX en Colombia," Análisis. Revista colombiana de humanidades, no. 79 (2011): 75-76. 
Revista colombiana de humanidades, no. 79 (2011): 69-101.

Caballero Gómez, Gumersindo, Juan Marchena Fernández, y Diego Torres Arriaza. El ejército de América antes de la Independencia: ejército regular y milicias americanas, 1750-1815; hojas de servicio, uniformes y estudio histórico. Madrid: Fundación Mapfre Tavera, 2005. CD.

Castillo, Lina del, María del Rosario Leal, y Grace McCormick. Iconografía intelectual en el Virreinato de la Nueva Granada siglo XVIII. Bogotá: Universidad Externado de Colombia, 2013.

Duque, María Fernanda. "Legislación gremial y prácticas sociales: los artesanos de Pasto (1796-1850).” Historia Critica, no. 25 (2003): 115-36.

Fajardo de Rueda, Marta. "La obra artística de la Real Expedición Botánica del Nuevo Reino de Granada en el siglo XVIII, 1783-1816.” Revista Ensayos. Historia y teoria del arte, no. 1 (1993-1994): 103-30.

---. "Instrucción general para los gremios, Santafé, 1777." Ensayos. Historia y Teoría del Arte, no. 1 (1995): 187-215.

---. "Diccionario de oribes y plateros en la Nueva Granada, siglos XVI, XVII, XVIII y XIX." Ensayos. Historia y teoría del arte, no. 6 (2000): 208-65.

Franco, Luis Fernando. "Los artesanos de Antioquia a fines del período colonial: una mirada a través de la Instrucción General para los Gremios de 1777.” Historia y Sociedad, no. 26 (2014): 81-97.

Gaitán Bohórquez, Julio. "Agenda ilustrada y agenda republicana en la cuestión educativa neogranadina." Rhela, no. 14 (2010): 100-24.

Gállego, Julián. El pintor, de artesano a artista. Granada: Universidad de Granada, 1976.

Garzón Marthá, Álvaro. Historia y catálogo descriptivo de la imprenta en Colombia (1738-1810). Bogotá: Gatos Gemelos Comunicación, 2008.

Gayoso Carreira, Gonzalo. Historia del papel en España 1. Lugo: Servicio de publicaciones Diputación de Lugo, 1994.

Giraldo Jaramillo, Gabriel. El grabado en Colombia. Bogotá: Editorial ABC, 1960.

---. "Visita al taller de un pintor de la época colonial." Boletín del Museo de Arte Colonial 1, no. 12 (1961): 3-11.

---. La miniatura, la pintura y el grabado en Colombia. Bogotá: Instituto Colombiano de Cultura, 1980.

González Quintero, Nicolás Alejandro. "Se evita que de vagos pasen a delincuentes: Santafé como una ciudad peligrosa (1750-1808).” Anuario Colombiano de Historia Social y de la Cultura 37, no. 2 (2010): 17-44.

Groot, José Manuel. Historia eclesiástica y civil de Nueva Granada. T. 2. Bogotá: Casa Editorial de M. Rivas, 1890.

Hernández de Alba, Guillermo. Teatro del arte colonial. Primera Jornada. Bogotá: Ministerio de Educación Nacional, 1938.

---. Documentos para la historia de la educación en Colombia. Bogotá: Patronato Colombiano de Artes y Ciencias - Colegio Máximo de las Academias Colombianas, 1983.

Ibáñez, Pedro María. Memorias para la historia de la medicina en Santafé de Bogotá. Bogotá: Fundación Editorial Epígrafe, 2006.

"Las actas de exámenes de los artesanos de Popayán." Boletín Histórico. Universidad del Cauca. Archivo Central del Cauca, no. 2 (1954): 3-14.

López Bejarano, Pilar. "Control y desorden en Santa Fe de Bogotá (Nueva Granada). En torno a las reformas urbanas de finales del siglo XVIII." BROCAR, no. 30 (2006): 111-37.

López Pérez, María del Pilar. "El barniz de Pasto. Encuentro entre tradiciones locales y foráneas que han dado identidad a la región andina del sur de Colombia." En Patrimonio cultural e identidad, 225-34. Madrid: Ministerio de Cultura de España, 2007. 
---. "Quito, entre lo prehispánico y lo colonial. El arte del barniz de Pasto.” En Arte quiteño más allá de Quito, 44-63. Quito: Fondo de Salvamento del Patrimonio Cultural de Quito FONSAL, 2007.

López Pérez, María del Pilar, y Laura Liliana Vargas Murcia. "La estampa en el periodo colonial." En Historia del grabado en Colombia, editado por Centro Cultural y Educativo Español Reyes Católicos y Álvaro Medina, 11-61. Bogotá: Editorial Planeta Colombiana S.A., 2009.

López Pérez, María del Pilar, y Museo de la Independencia - Casa del Florero. Más que muebles. Diseño en tiempo de independencias. Bogotá: Ministerio de Cultura de Colombia, 2012. http://www.museoindependencia.gov.co/que-hacemos/exposiciones/Exposiciones-de-larga-y-corta-duracion/PDF\%20Exposiciones/Mas\%20que\%20muebles.pdf

Marchena Fernández, Juan. Ejército y milicias en el mundo colonial americano. Madrid: Editorial Mapfre, 1992.

Martínez, Francisco. Introducción al conocimiento de las Bellas Artes o Diccionario manual de pintura, escultura, arquitectura y grabado con la descripción de varios autores, asi nacionales como extranjeros para el uso de la juventud española. Madrid: Imprenta Viuda del escribano, 1788.

Martínez Garnica, Armando, y Daniel Gutiérrez Ardila (eds.). Quién es quién en 1810. Guía de forasteros del Virreinato de Santafé para el primer semestre de 1810. Banco de la República, Biblioteca Luis Ángel Arango Virtual, 2010. http://babel.banrepcultural.org/cdm/ref/collection/p17054coll10/id/0

Mayor Mora, Alberto. Cabezas duras y dedos inteligentes. Estilo de vida y cultura técnica de los artesanos colombianos del siglo XIX. Medellín: Hombre Nuevo Editores, 2003.

Medina, Álvaro. Procesos del arte en Colombia 1 (1810-1930). Bogotá: Universidad de los Andes, 2013.

Mutis, José Celestino. Archivo epistolar del sabio naturalista don José Celestino Mutis. Compilado y con notas de Guillermo Hernández de Alba. T. 1, Vol. 3. Bogotá: Instituto Colombiano de Cultura Hispánica, 1968.

Ortega Ricaurte, Carmen. Diccionario de artistas en Colombia. Banco de la República, Biblioteca Luis Ángel Arango Virtual, 1965. http://babel.banrepcultural.org/cdm/ref/collection/p17054coll10/id/2732

Pachón Acero, Yolanda. Caracterización técnica de la escultura policromada en la Nueva Granada. Bogotá: Universidad Externado de Colombia, 2017.

Paniagua Pérez, Jesús. "La enseñanza de oficios mecánicos en Nueva Granada en vísperas de la Independencia." Trocadero, no. 24 (2012): 105-24.

Puentes Cala, Mauricio. "Milicianos y milicias en la Provincia de Santa Fe: Una vista desde el sector subordinado (1781-1788)." Cambios y permanencias, no. 3 (2012): 420-64.

Real Decreto e Instrucción General de Rentas Reales. Barcelona: Imprenta de Antonio Brusi, 1816.

Real Sociedad Económica Matritense. Memorias de la Sociedad Económica 4. Madrid: Impreso por Antonio de Sancha, 1787.

Recopilación de las Leyes de los Reynos de Las Indias. Mandadas imprimir, y publicar por la Magestad Católica del Rey Don Carlos II Nuestro Señor. 4 t. Madrid: Ivlian de Paredes, 1681; México: Facsimilar de Miguel Ángel Porrúa, 1987.

Reglamento para las milicias de infantería y caballería de la Isla de Cuba: Aprobado por S. M. Lima: Imprenta de la Real Casa de los Niños Expósitos, 1793.

Rey Márquez, Juan Ricardo. "Sobre el concepto de gusto en el Prontuario Artístico de Francisco Martínez D’Acosta: un capítulo olvidado de la estética iberoamericana." Boletín de Estética, año 6, no. 15 (diciembre 2010-marzo 2011): 31-63.

---. "El dibujo en Nueva Granada en el contexto de las reformas borbónicas.” Kaypunku 3, no. 2 (junio 2016): 95-116. 
Rey Márquez, Juan Ricardo, y Carolina Vanegas Carrasco. Noticias iluminadas: Arte e identidad en el siglo XIX. Bogotá: Alcaldía Mayor de Bogotá, Fundación Gilberto Alzate Avendaño, 2011.

Santa Cruz, Miguel Jernónimo de. Dorador contador. Aritmética especulativa y práctica: Contiene la fineza y reglas de contar oro y plata, y los aneages de Flandes por moderno y compendioso estilo. Madrid: Imprenta de Don Benito Cano, 1794.

Sañudo, José Rafael. Apuntes sobre la historia de Pasto. La Colonia bajo la Casa de Borbón. Pasto: Imprenta La Nariñense, 1940.

Silva, Renán. Los ilustrados de la Nueva Granada, 1760-1808. Genealogía de una comunidad de interpretación. Medellín: Banco de la República y EAFIT, 2002.

Solano D., Sergio Paolo. "Entre pinceles y armas. Pablo Caballero Pimentel, pintor y capitán de Milicias pardas en Cartagena de Indias, siglo XVIII.” Amauta, no. 20 (julio-diciembre 2012): 25-59.

Solano D., Sergio Paolo, y Roicer Flórez Bolívar. “'Artilleros pardos y morenos artistas': artesanos, raza, milicias y reconocimiento social en el Nuevo Reino de Granada, 1770-1812." Historia Crítica, no. 48 (2012): 11-37.

Taboada y Ulloa, Juan Antonio. Antorcha aritmética práctica, provechosa para tratantes y mercaderes. Instruye á los principiantes con Reglas del Arte Menor, y muchas breves para reducir las Monedas de Castilla unas en otras. Declara modo seguro de comerciar con dichas monedas, la cobranza de vales, y letras de todas partes, $y$ otras curiosidades. Madrid: Impresa por Ramón Ruiz, 1795.

Vargas Murcia, Laura Liliana. "Aspectos generales de la estampa en el Nuevo Reino de Granada (Siglo XVI - Principios del siglo XIX).” Fronteras de la Historia 14, no. 2 (2009): 256-81.

---. Del pincel al papel: fuentes para el estudio de la pintura en el Nuevo Reino de Granada (1552-1813). Bogotá: Instituto Colombiano de Antropología e Historia - ICANH, 2012.

---. "Estampas europeas en el Nuevo Reino de Granada (siglos XVI-XIX)." Tesis Doctoral, Universidad Pablo de Olavide, 2013.

---. "Religiosas pero prohibidas: Control en la circulación de estampas en el Nuevo Reino de Granada." Ensayos. Historia y teoría del arte 19, no. 28 (2015): 16-28.

---. “Del arte de pintores." En Catálogo Museo Colonial. Vol. I: Pintura, 67-83. Bogotá: Ministerio de Cultura, 2016.

Fecha de recepción: 15/11/2018

Fecha de revisión: 21/11/2018

Fecha de aceptación: 07/03/2019 